$5-28-2021$

\title{
Art as Atrocity Prevention: The Auschwitz Institute, Artivism, and the 2019 Venice Biennale
}

Kaitlin Murphy

The University of Arizona

Follow this and additional works at: https://digitalcommons.usf.edu/gsp

\section{Recommended Citation}

Murphy, Kaitlin (2021) "Art as Atrocity Prevention: The Auschwitz Institute, Artivism, and the 2019 Venice Biennale," Genocide Studies and Prevention: An International Journal: Vol. 15: Iss. 1: 68-96.

DOI:

https://doi.org/10.5038/1911-9933.15.1.1796

Available at: https://digitalcommons.usf.edu/gsp/vol15/iss1/8

This Articles is brought to you for free and open access by the Open Access Journals at Digital Commons @ University of South Florida. It has been accepted for inclusion in Genocide Studies and Prevention: An International Journal by an authorized editor of Digital Commons @ University of South Florida. For more information, please contact digitalcommons@usf.edu. 
Art as Atrocity Prevention: The Auschwitz Institute, Artivism, and the 2019 Venice Biennale

\section{Acknowledgements}

With deepest thanks to Tibi Galis, Aida Sehovic, Kerry Whigham, and Linda Young for their openness and generosity. 


\author{
Kaitlin Murphy \\ The University of Arizona \\ Tucson, Arizona, USA
}

\begin{abstract}
I'm frustrated by the approaches to genocide and war that have almost become so sanitized and professional. It's like its own economy. There are the people who produce the weapons, the people who buy the weapons, the people who fire the weapons, there are the first aid responders who respond to emergency situations.... There's a whole system that functions around genocide. I understand, but it's fucked up. I don't know how else to say it.... I'm not trying to devalue the way in which these things are addressed, but it's literally become a business and a profession for organizations and countries and people and all of it feeds off of each other, and it works for everybody who is part of this ecosystem for it to continue in this way. I think art disrupts this.
\end{abstract}

—Aida Šehović. ${ }^{1}$

The Venice Art Biennale, often referred to as the "art Olympics" and widely considered the preeminent international art fair, ${ }^{2}$ is likely not the very first place that comes to mind when one thinks of genocide and atrocity prevention. Ralph Rugoff, curator of the 58th occurrence of the Venice Biennale, which was titled "May You Live in Interesting Times" and took place in 2019, went so far as to proclaim in the opening sentences of his official introduction to the Biennale that we should "acknowledge at the outset that art does not exercise its forces in the domain of politics." 3 While this is an extremely debatable claim, and one with which many Biennale artists would likely take issue, it nonetheless remains true that, for most audiences, the sprawling Biennale is more likely to be associated with top notch contemporary art and transnational economies of influence and access than it is with human rights. Yet, the Auschwitz Institute for the Prevention of Genocide and Mass Atrocities (Auschwitz Institute), ${ }^{4}$ one of the leading NGOs working to prevent future violent conflict, chose to curate an art exhibit in 2019 alongside the Biennale. In the context of genocide and mass atrocity prevention, what is the potential intervention of an exhibition such as this one? This is linked to a much larger question driving this article: what is the role of the arts in the prevention of genocide and mass atrocities?

\footnotetext{
${ }^{1}$ Aida Šehović, in conversation with the author, June 2020.

2 Oscar Boyson, dir., "Behind the Biennale: A Short History of the World's Most Important Art Exhibition," uploaded May 3, 2015, Artsy, 00:00:29, accessed June 20, 2020, https://www.artsy.net/article/artsy-editorial-behind-thevenice-biennale-2015-a-short-history-of-the-world-s-most-important-art-exhibition.

3 Ralph Rugoff, “Introduction by Ralph Rugoff: Curator of the 58th International Art Exhibition," La Biennale di Venezia, accessed May 1, 2019, https://www.labiennale.org/en/art/2019/introduction-ralph-rugoff.

4 The Auschwitz Institute for Genocide and Mass Atrocity Prevention changed its name in December 2019. The organization was still using its previous name, the Auschwitz Institute for Peace and Reconciliation, when the exhibition opened in May 2019.
}

Kaitlin Murphy. "Art as Atrocity Prevention: The Auschwitz Institute, Artivism, and the 2019 Venice Biennale." Genocide Studies and Prevention 15, no. 1, 68-96. https://doi.org/10.5038/1911-9933.15.1.1796.

(C) 2021 Genocide Studies and Prevention. 
While an exhaustive sweep of all arts initiatives ${ }^{5}$ is vastly beyond the scope of this article, I focus here on the Auschwitz Institute's 2019 Venice Biennale exhibition, titled "Artivism: The Atrocity Prevention Pavilion," and draw from fieldwork, interviews, and extensive secondary research to argue that the arts can in fact make powerful contributions to the prevention of genocide and mass atrocity. In what follows, I describe my analytic approach and provide a brief introduction to the Auschwitz Institute, the Venice Biennale, and the artwork in the Artivism Pavilion. I then turn to scholarship on prevention in order to lay the groundwork for analysis in the broader context of mitigating risk factors associated with past and future violent conflict. Ultimately, I argue that although largely overlooked in genocide and atrocity prevention scholarship, the arts have a central role to play in genocide and atrocity prevention efforts.

\section{Approach}

Measuring the preventive capacity of the arts—or anything-is challenging because it relies on establishing proof of a non-event. In practical terms, it is nearly impossible to prove with any certainty that atrocity definitely would have occurred but did not directly because of another intervening factor. Moreover, in the context of measuring impact, the question of what and how much art can actually do will almost always eventually arise. In other words, how do we know when art "worked" - and what does "working" mean? Complicating the question of how the arts might work in fostering change is the problem of accounting for change itself. Change is largely nonlinear and unpredictable, occurring over time, and the result of myriad efforts on multiple fronts. How, then, to determine the impact of the arts in atrocity prevention?

First and foremost, it is critical that analysis be grounded in a fundamental understanding of the complexity of change. In "The Limits of Nonprofit Impact," authors Ebrahim and Rangan describe two types of theories of change: a focused theory and a complex theory. ${ }^{6} \mathrm{~A}$ focused theory of change has a linear notion of cause and effect. As Ebrahim and Rangan explain, in the aftermath of atrocity, many forms of emergency response operate on a more easily measured, focused theory of change, such as getting food and water to survivors. While the logistics of such relief efforts are often complicated, the logic-and measurable outcomes-are fairly straightforward: the food arrived or it didn't.7 A complex theory of change, on the other hand, has a less definitive notion of cause and effect and recognizes that many causal factors outside of the project's reach are also at play. The distinction is fairly simple but incredibly important, especially in the context of atrocity prevention. A fairly straightforward example of the importance of this distinction in impact measurement is arts programming for children in refugee camps. Using a focused theory of change, if children who receive more arts programming are surveyed and shown to be happier than students who do not, it is a success. A complex theory of change, however, recognizes that there are many other contributing factors beyond the project's control. The arts programming may well be an important factor, but it is not the only factor. The complex, multifaceted work of meaningful and lasting atrocity prevention necessitates complex theories of change.

This is especially true in the case of any exhibition and especially this one, which included artworks from a wide range of geographic and cultural contexts. It is important to note

\footnotetext{
${ }^{5}$ My definition of arts initiative is expansive across medium and method; and includes art such as film and photography, painting and drawing, literature and storytelling, dance, theater and performance, murals, music, and monuments and memorials, arts education programs, arts festivals, exhibits, and community arts collectives. While perhaps obvious, it is worth underscoring that not all art is intended to engage in the sociopolitical milieu of the times or enact change. My focus here is on those artworks, projects, and practices that do.

${ }^{6}$ Alnoor Ebrahim and V. Kasturi Rangan, "The Limits of Nonprofit Impact: A Contingency Framework for Measuring Social Performance," (working paper no. 10-099, Harvard Business School, Cambridge, MA, 2010), 22.

7 Ibid., 19.
} 
that the exhibition was received quite positively by visitors; ${ }^{8}$ and research shows that such an experience can result in increased public awareness, which in turn leads to increased public engagement, strengthened social movements, and, ultimately, social change. ${ }^{9}$ However, it is all but impossible to definitively prove that a visit to an international art exhibition directly resulted in atrocity prevention-there are simply too many variables. Thus, while audience response is useful to a certain extent (and it is indeed meaningful that feedback was positive), this article takes a different methodological approach and instead analyzes the artworks themselves through the lens of atrocity prevention.

While the field of genocide studies lacks sustained research into the role of the arts in prevention, I draw here from research into the impact of the arts in society more broadly and combine it with the thorough research into the risk factors for genocide and atrocity. This overlay of research fields, combined with fieldwork and interviews, creates the foundation for investigation into how different arts initiatives have directly mitigated one or more atrocity risk factors. These established risk factors emerge from a number of well-known and respected early-warning systems that have been developed over the last decade and draw from a diverse range of qualitative and quantitative data to predict the risk for genocide, state-led mass killing, and/or atrocities. In Confronting Evil: Engaging Our Responsibility to Prevent Genocide (2016), James Waller writes that these different prevention systems are "developed and used by national governments, militaries and intelligence services, international and regional organizations, academics, nongovernmental organizations, civil society, think tanks, and private enterprises" to analyze a range of early warning signs, such as political instability, state fragility, and civil unrest. ${ }^{10}$ Such early warning systems include the Atrocity Forecasting Project at Australian National University, ${ }^{11}$ the United Nation's Framework of Analysis for Atrocity Crimes, 12 the University of Maryland's Minorities at Risk Project, 13 the Early Warning Project at the United States Holocaust Memorial Museum, ${ }^{14}$ and Barbara Harff's model of risk factors for genocide and politicide. ${ }^{15}$ In Confronting Evil, Waller analyzed the specific risk factors identified across these different early warning systems and produced a list of twenty risk factors that he divided into four different categories: governance, conflict history, economic conditions, and social fragmentation. ${ }^{16}$ In what follows, I build from Waller's comprehensive, comparative

8 I interviewed both Kerry Whigham and Tibi Galis for this article (in May and June 2020, respectively), and they each shared strong positive feedback received from local and international audiences alike (including an array of state officials and government representatives). This anecdotal feedback was corroborated by my July 2019 fieldwork, during which I observed visitors' responses to the exhibit and spoke with exhibition staffers about their experiences observing visitors make their way through the exhibit.

${ }_{9}^{9}$ Meg McLagan, "Imagining Impact: Documentary Film and the Production of Political Effects," in Sensible Politics: The Visual Culture of Nongovernmental Activism, ed. Meg McLagan and Yates McKee (New York: Zone Books, 2012), 312.

10 James Waller, Confronting Evil: Engaging Our Responsibility to Prevent Genocide (New York: Oxford University Press, 2016), 149.

11 "Atrocity Forecasting Project," Australian National University, accessed July 10, 2020, https:/ / politicsir.cass.anu.edu.au/ research/projects/atrocity-forecasting.

12 United Nations, Framework of Analysis for Atrocity Crimes: A Tool for Prevention (UN Office on Genocide Prevention and the Responsibility to Protect, 2014).

13 “The Minorities at Risk (MAR) Project," University of Maryland, accessed June 30, 2020, http:/ / www.mar.umd.edu/.

14 "Early Warning Project," United States Holocaust Memorial Museum and Dartmouth College, accessed June 1, 2020, https:/ / earlywarningproject.ushmm.org/.

15 Barbara Harff, "Assessing Risk of Genocide and Politicide," in Peace and Conflict: A Global Survey of Armed Conflicts, Self-Determination Movements, and Democracy, ed. Monty G. Marshall and Ted Robert Gurr (College Park: University of Maryland Press, 2005), 57-61.

16 Waller, Confronting Evil, 151. 
approach to analyze how arts initiatives can and have successfully mitigated risk factors in three of the four categories: conflict history, social fragmentation, and governance. ${ }^{17}$

\section{Atrocity Prevention in Venice?}

Founded in 2008, and with offices in Buenos Aires, Kampala, New York, and Oświęcim, the Auschwitz Institute's genocide and atrocity prevention work predominantly comprises comprehensive training, education, and technical assistance intended to help states around the world strengthen their prevention policies and practices, and cultivate regional and international support and accountability networks. ${ }^{18}$ Their approach is grounded in the understanding that genocides can occur anywhere but do not spontaneously occur-rather, they are the result of "distinct political and social actions" and "preceded by a steady stream of warning signs."19 As such, the Auschwitz Institute has worked to "operationalize the identification of critical risk factors, providing officials with concrete frameworks to respond to these warning signs before they can gain deadly momentum, protecting the fundamental human rights of their populations." 20 The arts are not a primary programmatic area for the Auschwitz Institute, but Dr. Tibi Galis, executive director of the Auschwitz Institute, explained in a June 2020 interview that participation in the Biennale was not as much of a departure as it first may seem..$^{21}$ Because the majority of the Auschwitz Institute's work tends to occur behind the scenes, their participation in cultural projects is not always visible, but the organization has engaged in a number of culturally-focused projects as part of its broader body of prevention work. This includes ongoing support and technical assistance to the Kenyan National Committee for Genocide Prevention toward the establishment of the Never Again Memorial in Nairobi and co-organization of various artistic programs related to memorialization and atrocity prevention in Kigali, Rwanda (2017), Oświęcim, Poland (2017), and Buenos Aires, Argentina (2018).22

Periodic attendance at the Biennale over the years had left Galis with the sense of an untapped opportunity to build connections between the art world and the Auschwitz Institute's work in atrocity prevention. Since its inception in 1895, the Venice Biennale has grown to be one of, if not the most important international contemporary art exhibition and encompasses

17 Due to space limitations, it is beyond the scope of this article to include all four categories, but there has been substantial research into economic conditions and the impact of the arts. For example, the National Endowment for the Arts' Office of Research \& Analysis and the U.S. Commerce Department's Bureau of Economic Analysis jointly produce the U.S. Arts and Cultural Production Satellite Account, which analyzes the size of the arts and cultural sector and its contributions to the U.S. economy, the number of workers employed by those industries and their compensation figures, consumer expenditures on arts and culture, and import/export activity. See "Arts Data Profile Series," National Endowment for the Arts, accessed April 24, 2021, https://www.arts.gov/impact/ research/arts-data-profile-series. There is also a plethora of sustainable creative economy development initiatives across the globe that are aimed at increasing financial self-sufficiency through arts and craft-the Intuthuko Embroidery Project in South Africa is a perfect example.

18 The Auschwitz Institute advocates for regional solutions to regional challenges and works to develop effective, regionally specific, multidimensional approaches to its work.

19 Deeply rooted in the memory and legacy of Auschwitz, one of the main pillars of the Auschwitz Institute's work is its landmark training program, the Raphaël Lemkin Seminar for Genocide Prevention. Held on site at AuschwitzBirkenau, the former Nazi concentration and extermination camp, now memorial and museum, the Seminar draws from the power of place and lessons from the past to create powerful learning opportunities for participants and to promote their ongoing commitment to atrocity prevention. See "Lemkin Seminar, Global Edition," Auschwitz Institute for the Prevention of Genocide and Mass Atrocities, accessed April 23, 2021, https:// www.auschwitzinstitute.org/what-we-do/global-programs/.

${ }^{20}$ Auschwitz Institute for Peace and Reconciliation, Artivism: The Atrocity Prevention Pavilion, 2019 (pamphlet), 2.

21 Tibi Galis, in discussion with the author, June 2020.

22 Ibid. 
multiple exhibitions and events that collectively draw over 500,000 visitors each year. ${ }^{23}$ The core art exhibition is curated by that year's curator and displayed throughout two main exhibition spaces: a large exhibition hall known as the Giardini, and the Arsenale, a sprawling cluster of renovated shipyards, warehouses, and sheds adapted to be exhibition spaces. These exhibitions are accompanied by country pavilions ${ }^{24}$ and a range of officially and unofficially affiliated collateral exhibitions and events. Galis explained that even though the inclusive nature of the large Biennale did not lend to a coherent focus on human rights, the significant amount of politically-engaged art at the Biennale suggested its potential as a space for the Auschwitz Institute to reach a wider general audience for their message. At the same time, it presented an opportunity for the Auschwitz Institute to develop a large public facing project that would generate exposure for the Institute's work while also serving as a model for how ministries of culture could use their access to the arts circuit for atrocity prevention goals. Conversations with senior Biennale staff were quite positive, and the Auschwitz Institute team began developing their proposal. Rugoff's troublingly apolitical proclamation further underscored the importance of the Auschwitz Institute's intervention but also raised concerns that such a curator might not be receptive to an exhibition entirely about the relationship between art and politics. These concerns proved valid, and the Auschwitz Institute's proposal for an officially affiliated exhibition was rejected. Undeterred, the Auschwitz Institute decided to proceed with an unaffiliated collateral exhibition. ${ }^{25}$

The Auschwitz Institute's project lead for the exhibition, Dr. Kerry Whigham, worked to develop an exhibition that highlighted an array of distinctive ways artists and activists have used creativity to respond to large-scale identity-based violence and mass atrocity in varying conflict contexts and geographic regions across the globe. ${ }^{26}$ In a May 2020 interview, Whigham recalled, "a lot of people asked why we hadn't used the Holocaust as a case study, especially since we're the Auschwitz Institute. But the exhibition was taking place in Europe, and there's already so much awareness and action around the Holocaust in Europe. It felt important to choose cases that are less well-known." 27 The exhibition ultimately included works from artists and activist collectives from six countries, each from a different global region: Argentina, Bosnia and Herzegovina/US, Canada, Indonesia/Belgium, Iraq, and South Africa. Aptly named "Artivism," a portmanteau term combining art and activism that identifies artistic initiatives and practices using art to impact social change, 28 and housed in the Palazzo Dandolo Paulucci, an opulent old building mere steps from the Grand Canal in the heart of Venice, the Auschwitz

${ }^{23}$ The art exhibition typically takes place in odd-numbered years and the architecture, cinema, dance, music, and theater-focused exhibitions in even-numbered years. Due to the 2020 coronavirus pandemic, the 2020 architecture exhibition was postponed until 2021, and the art exhibition will also be delayed a year, to 2022. It is unclear if this is a temporary or permanent shift in schedule.

${ }^{24}$ Although all countries that wish to curate an exhibition may do so, the countries with permanent pavilions are strikingly reflective of the international politics of the 1930s and the Cold War. All other countries are assigned temporary space, for which they pay per square foot.

25 The United Nations High Commissioner for Refugees (UNHCR)'s proposal was similarly rejected, and they also chose to do an unaffiliated collateral exhibition.

${ }_{26}$ Two Italian curators, Luca Berta and Francesco Giubilei, who together run VeniceArtFactory, a local Venetian curatorial and exhibition production business, helped with the practical aspects of designing and installing the exhibition. They were also supported by Auschwitz Institute staff and local fixers in Venice.

${ }^{27}$ Kerry Whigham, in discussion with the author, May 2020.

28 The term artivism has been in circulation since at least 1997 when, following a gathering of Chicano artists from East Los Angeles and the Zapatistas in Chiapas, Mexico, the terms artivist and artivism were used by East LA artists Quetzal, Ozomatli, and Mujeres de Maiz, among others, to describe various events, actions, and artworks. The term is now commonly used in and by protest movements and in some academic writing to encompass a fairly wide range of artistic initiatives aimed at impacting social change (see, for example, Chela Sandoval's scholarship on Chicano/a art activism and M. K. Asante Jr.'s on Black art activism). Chela Sandoval and Guisela Latorre, "Chicana/o Artivism: Judy Baca's Digital Work with Youth of Color," in Learning Race and Ethnicity ed. Anna Everett (Boston: MIT Press, 2007), M. K. Asante Jr., It's Bigger Than Hip Hop (London: St. Martin's Press, 2009). 
Institute's exhibit officially opened to the public on May 9, 2019.29 In what follows, I offer a brief overview of the exhibit, then turn to scholarship on mitigating risk factors related to atrocity in order to further develop my analysis of art's role in prevention.

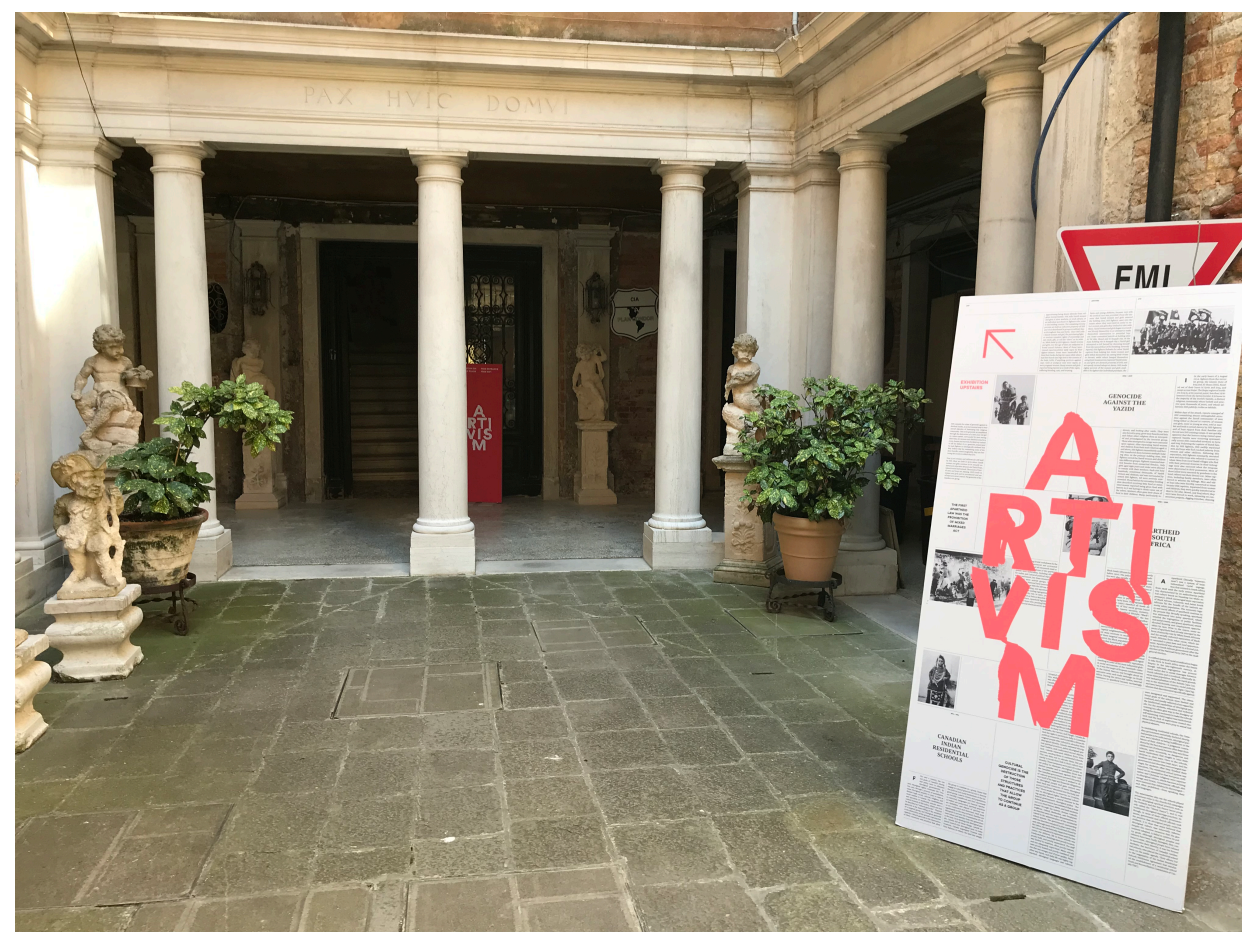

Image 1. Artivism entrance, courtesy of the author.

\section{Artivism: The Atrocity Prevention Pavilion}

The first room of Artivism, and the one through which visitors entered, was designed to resemble a cold, bureaucratic waiting room, reminiscent of those so often faced by genocide survivors and asylum seekers. This drab grey room was small and cramped, with hard plastic and metal chairs lined against two walls, a ticket dispenser, and a sign directly across from the entryway that read:

You have entered the waiting room.

Take a number from the machine.

Have a seat.

Wait for your number to be called to enter the exhibition.

This art experience starts here.

As ticket numbers appeared on a screen on the wall above the chairs, so too did the numbers often associated with genocide: "Holocaust: 6,000,000;" "Srebrenica: 8,373;" "Rwanda: $800,000 . "$ The room conveyed a sense of powerlessness, control, and selection. By asking visitors to watch for their entrance numbers amidst genocide death rates, curators placed visitors directly alongside the dead, thus reminding viewers that they are no different-they, too, could be a victim of genocide-and highlighting the dehumanizing nature of framing humans, and their deaths, in vacant statistical terms.

\footnotetext{
29 It closed on November 24, 2019 when the Biennale ended.
} 


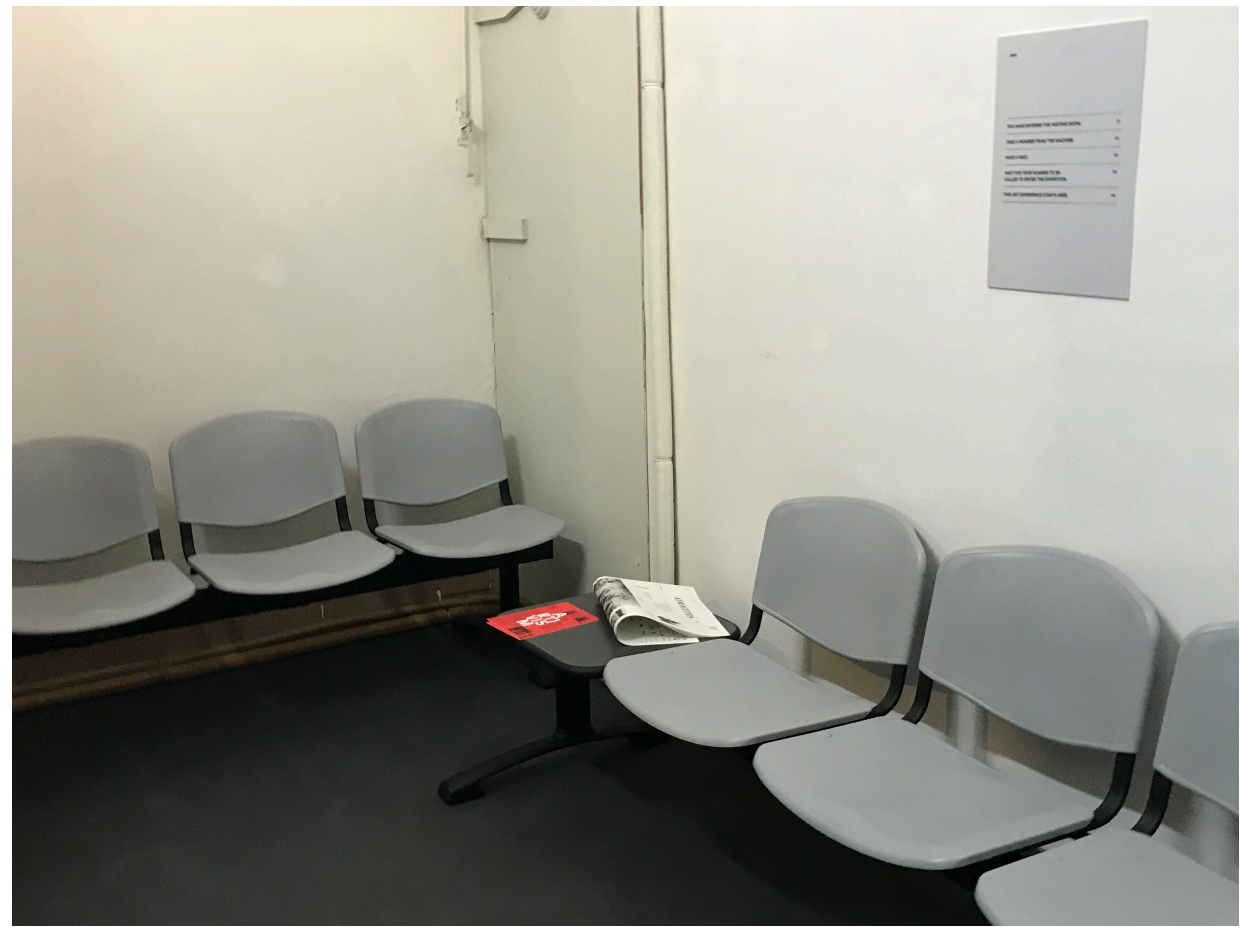

Image 2. Artivism "Waiting Room," courtesy of the author.

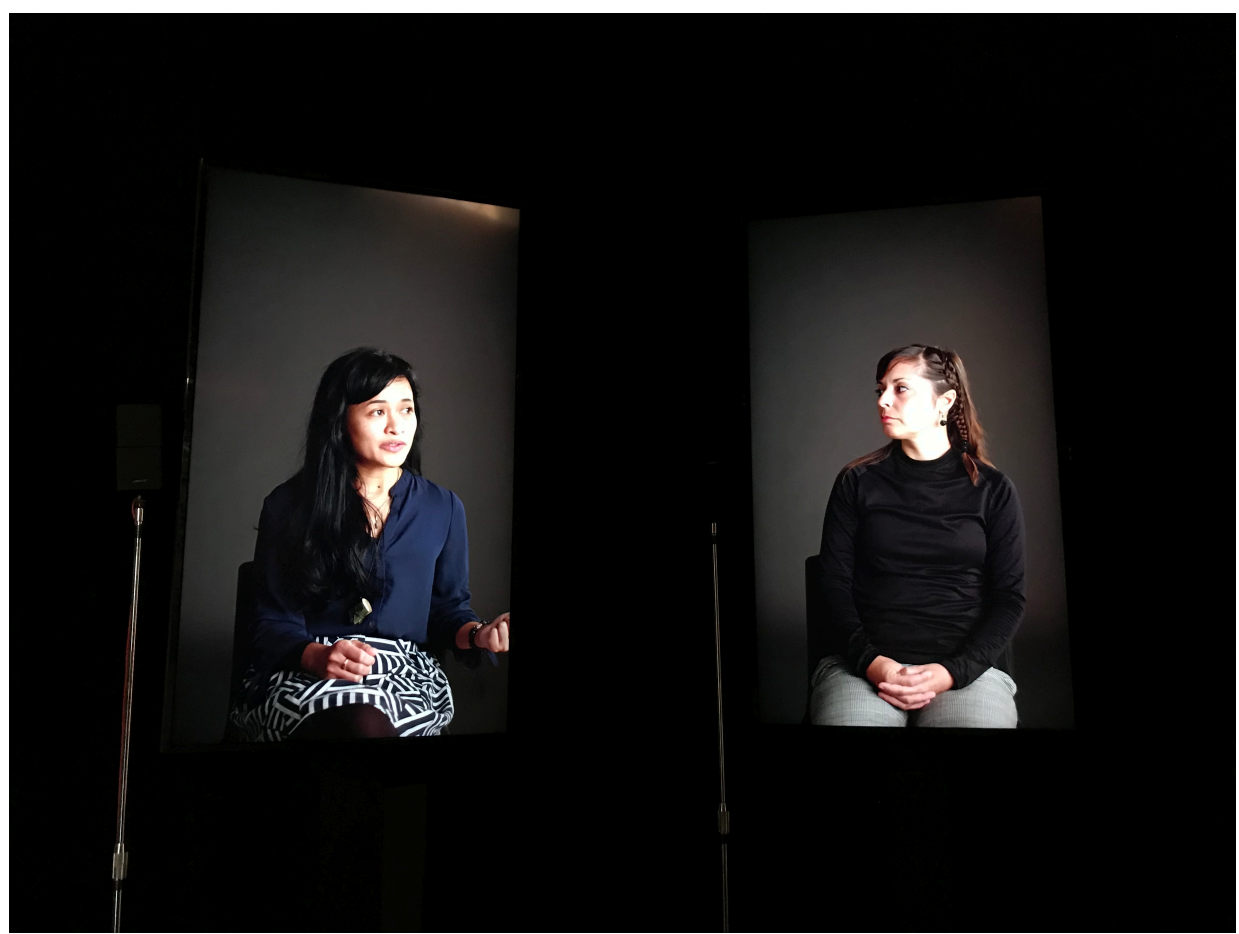

Image 3. The Artivism artists speak, courtesy of the author.

From the waiting room, visitors progressed to another small room; this one, dark with several chairs arranged to face three large screens. In direct contrast with the previous room, this room emphasized the individual human experience. A twenty-three-minute-long video installation played across the three screens, with the artists featured in the exhibition positioned sitting facing the camera against a black backdrop. Although each artist was interviewed alone, the video installation was edited so as to give the impression that the artists were in dialogue with each other as they gave historical background, outlined the atrocities experienced in their respective countries, and described how they used their art to impact change. Whigham said 
that it was important that visitors encountered the artists first-met them, heard their stories, and heard them talk about their art, without necessarily knowing what their art was explaining:

We wanted visitors to understand that these artists were normal people who used the tools that they have, which is art, to do something to transform their society. Everyone has a responsibility and the capacity to contribute to responding to past violence and responding to future violence from whatever position they have, whatever skills they have. ${ }^{30}$

The artworks were displayed throughout rooms, the smaller of which was accessible through a side doorway from the video installation. This room held just one artwork, ŠTO TE NEMA [translated: "Why are you not here?"], a memorial for the 8,373 Bosnian Muslims murdered in the Srebrenica genocide of July 1995 created by Bosnian artist Aida Šehović.

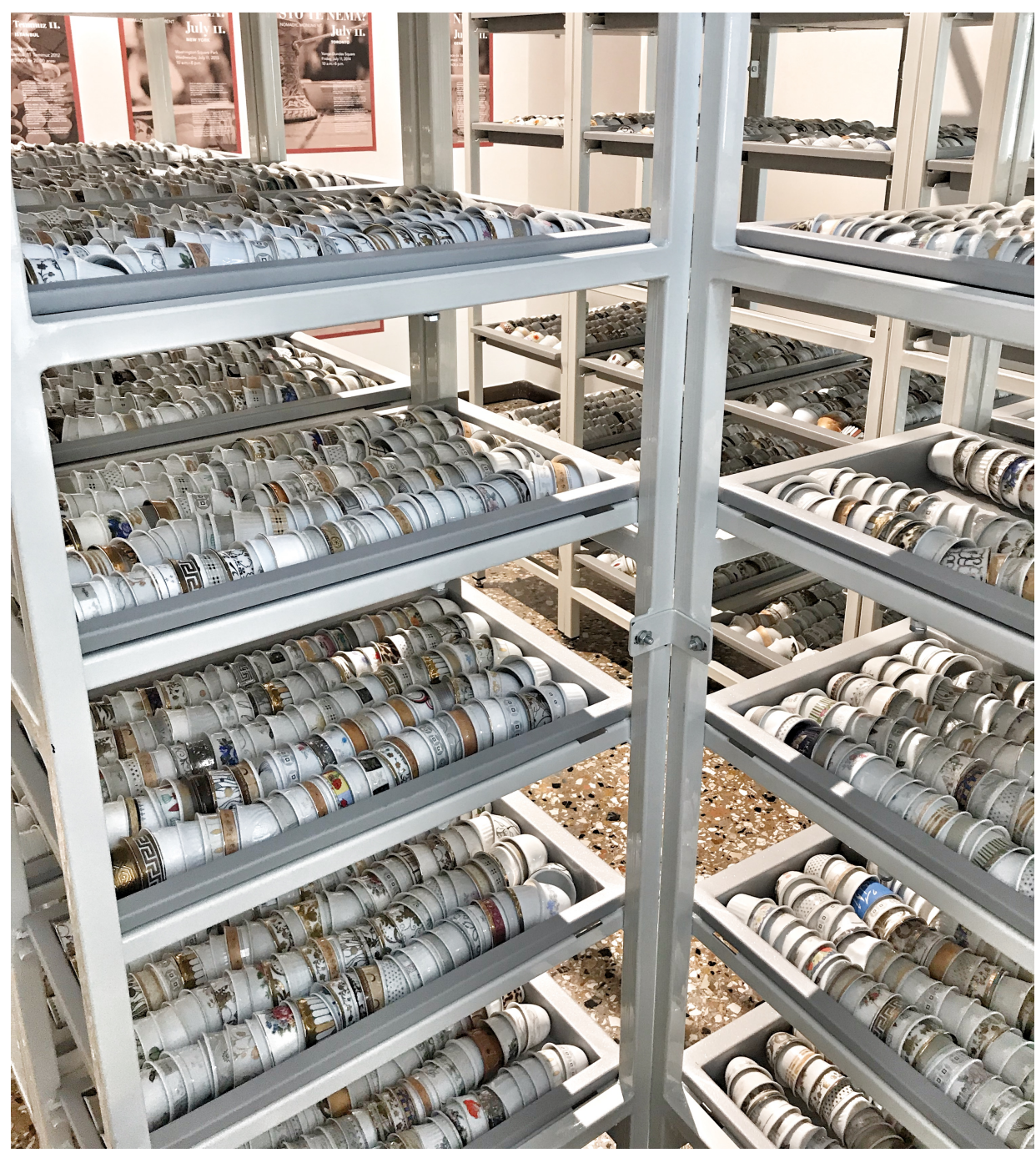

Image 4. STO TE NEMA as displayed in Artivism, courtesy of the author.

${ }^{30}$ Kerry Whigham, in discussion with the author, May 2020. 
The rest of the artwork was displayed in a large room overlooking the canal. Upon entering, visitors first encountered a small selection of testimonial artworks and objects on loan from the Canadian National Centre for Truth and Reconciliation archives. ${ }^{31}$ These were displayed alongside embroidered tapestries from the Intuthuko Embroidery Project, a women's community empowerment collective in Daveyton, South Africa, that uses embroidery to engage social issues and communicate about the traumas experienced and still carried in the aftermath of the long Apartheid regime in South Africa. ${ }^{32}$

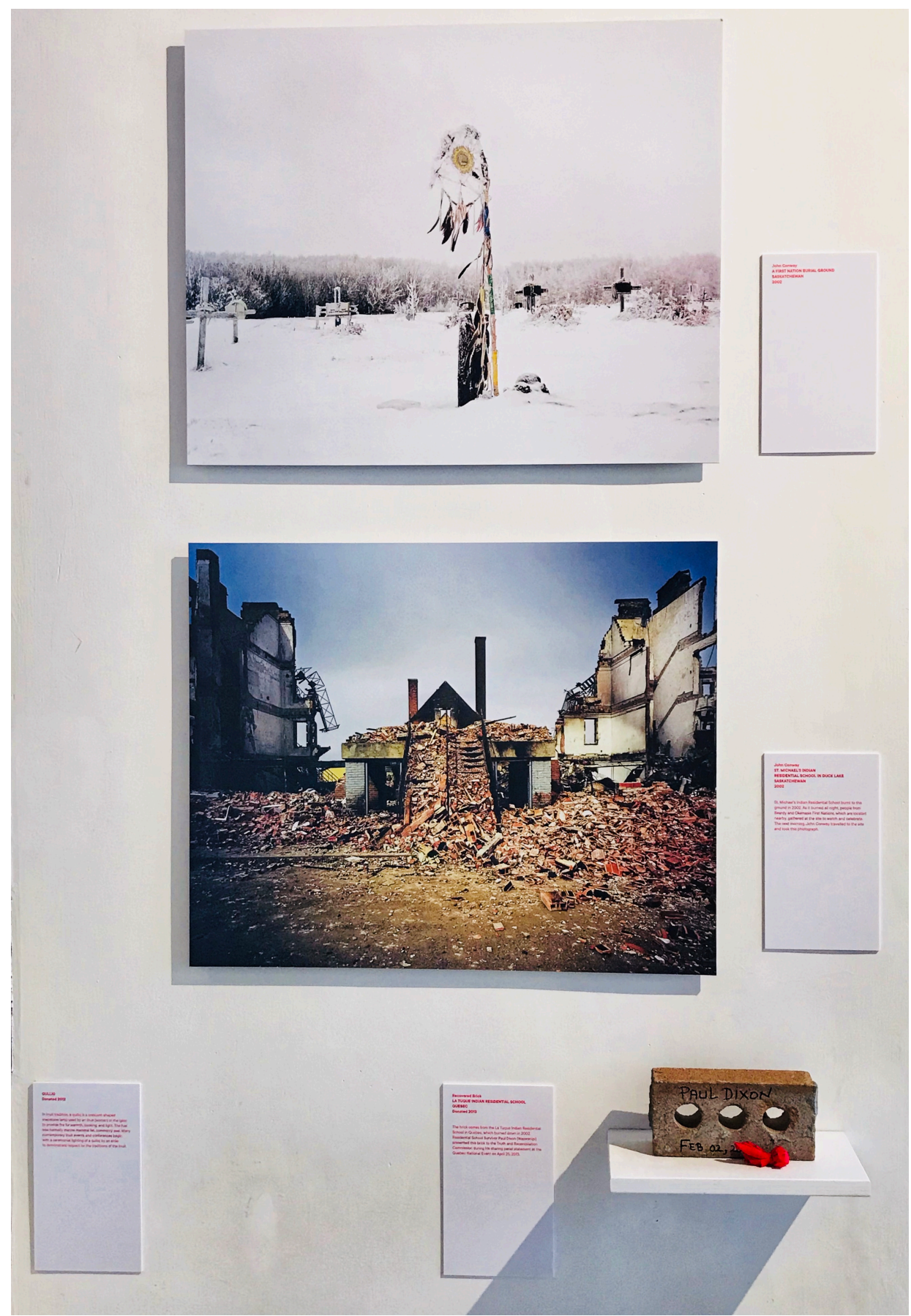

Image 5. Objects from the Canadian TRC archives as displayed in Artivism, courtesy of the author.

\footnotetext{
31 Canada's truth commission is the first and only commission to date to accept art as part of their testimonial process.

32 South Africa's oppressive authoritarian system of institutionalized racial segregation, known as Apartheid, lasted from 1948 until the early 1990s.
} 


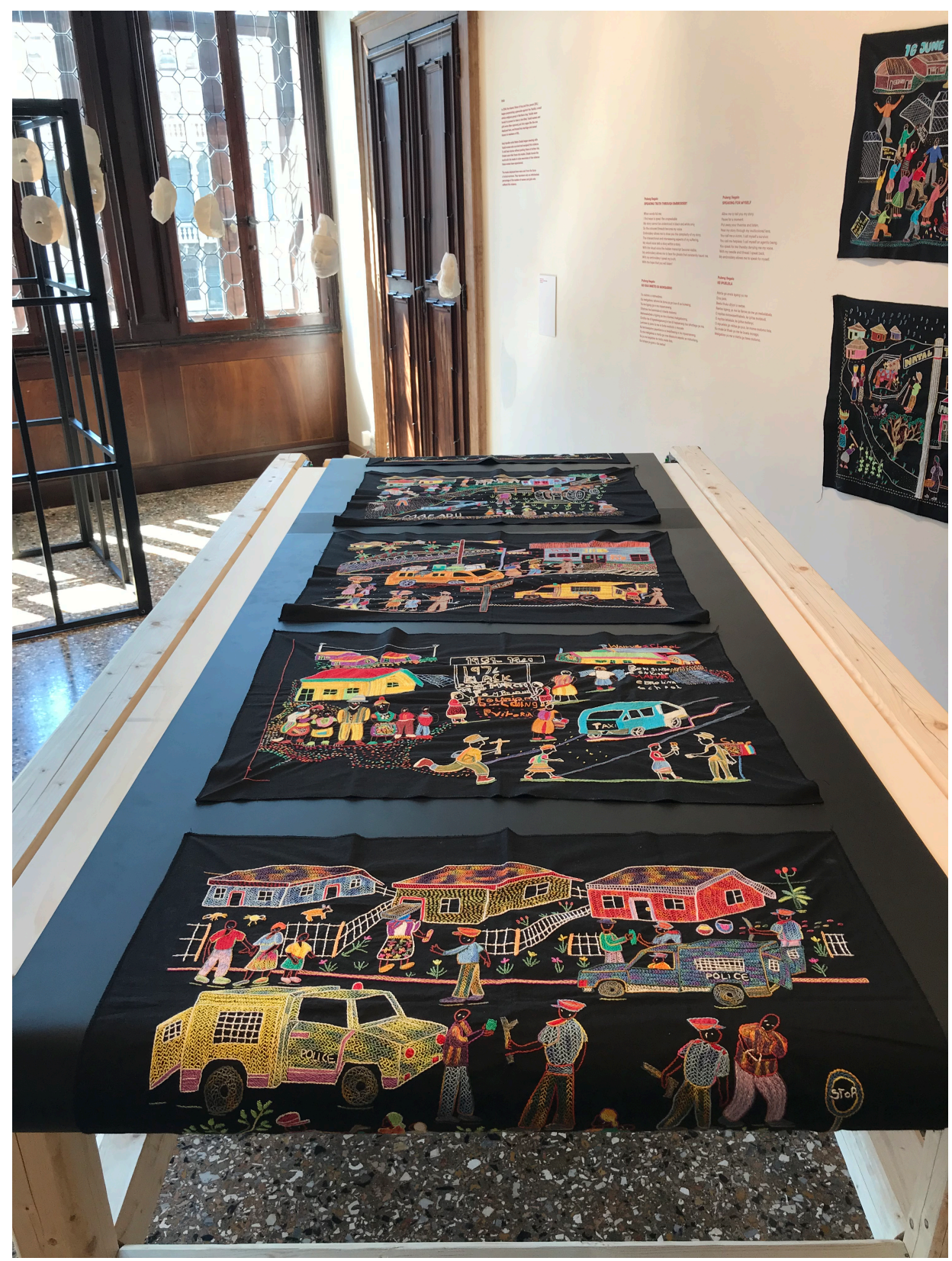

Image 6. The Intuthuko Embroidery Project tapestries as displayed in Artivism, courtesy of the author.

Yazidi Masks, an art installation made by Iraqi artist Rebin Chalak Ismael in response to the ongoing violence against the Yazidis, a small ethnic-religious group in Northern Iraq against whom the terrorist group known as ISIS 33 has been committing genocide since 2014, was displayed by the windows. Located along the opposite wall were two pieces by Elisabeth Ida Mulyani, an Indonesian artist based in Belgium whose work addresses how the 1965 mass killings of roughly 1.5 million people, due to their alleged ties to communism, continues to impact Indonesian life both in country and in the refugee diaspora.

${ }^{33}$ ISIS (Islamic State of Iraq and Syria) started as an al Qaeda splinter group and is also known as ISIL (Islamic State in Iraq and the Levant) and IS (Islamic State). 


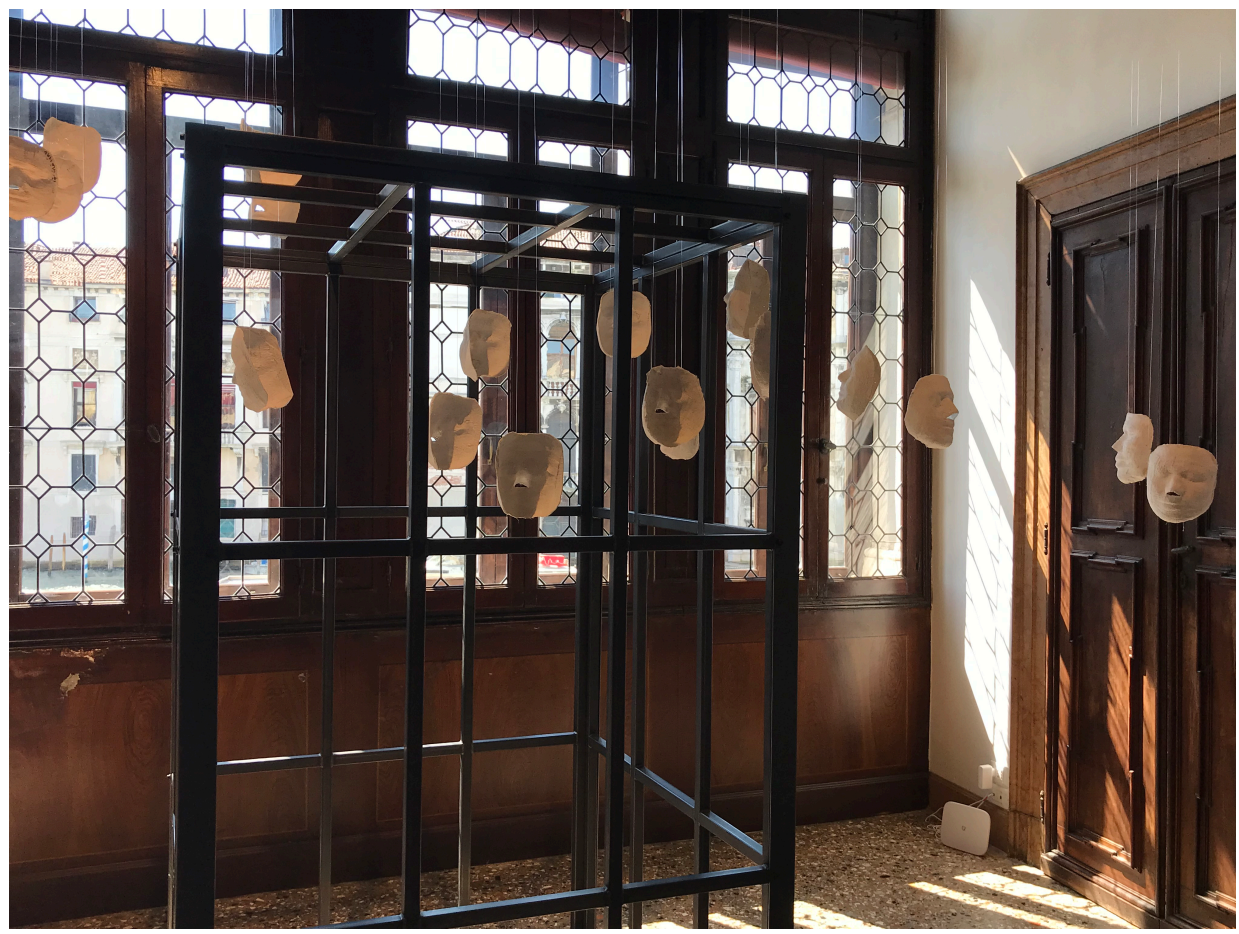

Image 7. Yazidi Masks as displayed in Artivism, courtesy of the author.

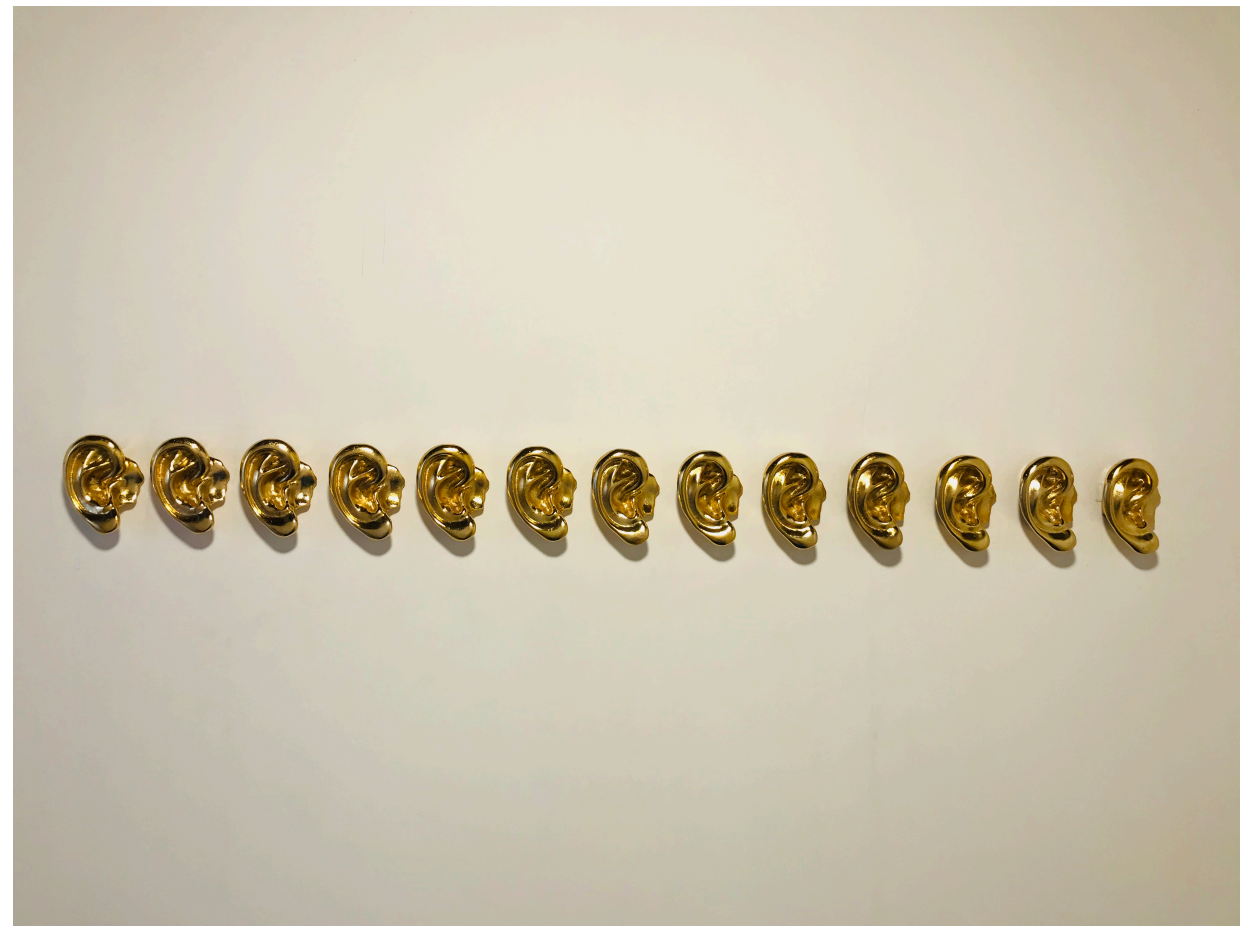

Image 8. Oleh-oleh, courtesy of the author.

The remaining contribution was by the Argentinian Grupo de Arte Callejero (GAC/ Street Artist group). When democratic governance was reestablished following Argentina's horrifically violent 1976-1983 military dictatorship, a number of laws and policies were swiftly passed granting impunity to guilty military leaders. In response, GAC began creating fake signs they then posted throughout the city in order to mark the homes of still-unpunished perpetrators, make visible the kidnapping, torture, and murder that had occurred, and denounce the crimes against humanity. Several of these signs were featured in Artivism, alongside photos, a video documentary, and a map installation. 


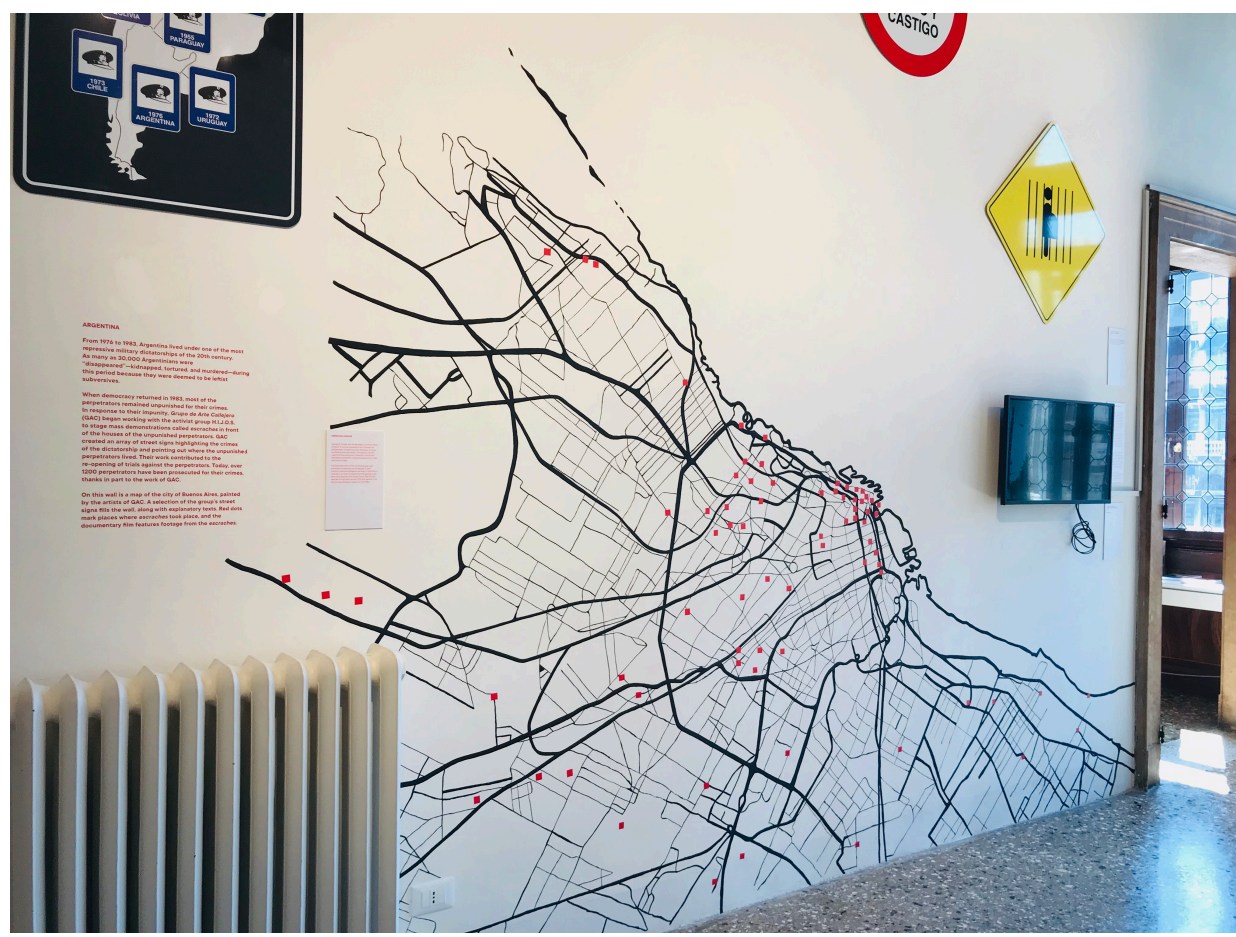

Image 9. GAC as exhibited in Artivism, courtesy of the author.

\section{$60 / 60 / 60$ CHALLENGE}

The artists and collectives featured in Artivism demonstrate that the prevention of mass atrocities and the protection of human rights requires engagement from all levels of society. But how can YOU get involved?

The four organizations featured in this room are all working for the prevention of identity-based violence and the promotion of human rights. Find an organization whose mission you support, then take their $60 / 60 / 60$ Challenge. Each organization has suggested three things YOU can do to be a part of the solution, whether you have 60 seconds, 60 minutes, or 60 days to dedicate.

Decide what you want to do, then take the corresponding pledge sheet off this wall. By taking a sheet, you're making a commitment to complete that task. You can even complete some of the tasks here in this room using your mobile devices and the free WiFi we provide.

Now join us in building a world of activists and artivists working for the rights of all!

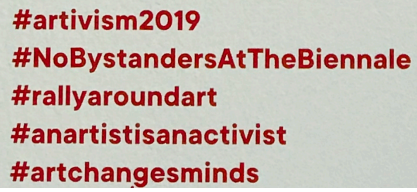

Image 10. Final room, courtesy of the author. 
Artivism culminated in a room intended to encourage visitors to reflect on their own role in mass atrocity prevention and the protection of human rights and to explore different ways they could take action. Different organizations and individuals taking an array of approaches to atrocity prevention were profiled on the walls, and visitors were presented with concrete steps they could take to become more involved. These steps were divided into three categories based on time commitment: sixty seconds, sixty minutes, or sixty days. These actions ranged from taking a minute to reflect on a time the visitor had been discriminated against due to their identity and a time when they had discriminated against someone else because of their identity, taking one hour before the next election to research what each candidate has proposed to do to protect the rights of a vulnerable identity group where the visitor lived, and researching and volunteering for an organization that actively protects the rights of a vulnerable group for sixty days. Having previously introduced visitors to the lived realities of mass atrocity and shown how artists and activists have used art to respond to widespread violence and help prevent its recurrence, this emphasis on the importance of collective action functioned as a powerful culminating message.

Taken as a whole, Artivism conveyed a strikingly coherent message about the quintessential role of the arts in the prevention of systematic violence and provided an array of diverse examples of how art may be used as a grassroots tool for addressing political violence and human rights abuses-and for advancing peacebuilding, transitional justice efforts, and prevention efforts. In what follows, I explore how the arts can and have successfully mitigated risk factors in three of the four categories outlined by Waller: conflict history, social fragmentation, and governance.

\section{Conflict History}

A history of genocide and atrocity is one of the more notably important indicators for future atrocity. Unfortunately, it's also one that can never be entirely eliminated-the past cannot be undone. Identity-related tensions and legacies of vengeance or group grievances often continue to exist after the conflict has ended, resulting in deep cultural cleavages that are kept alive and passed down through generations. Waller writes that group grievances grow out of the "painful legacies of groups that have been denied autonomy, self-determination, or political independence; subjected to institutionalized persecution, repression, oppression, or political exclusion; and victimized by nationalist political rhetoric or scapegoating." 34 These tensions can also be further exacerbated by a past record of serious violations of human rights and laws that has not been adequately or transparently addressed. These experiences leave the "aggrieved groups feeling as the 'other,' outside of the nation, voiceless and powerless in the face of their imposed marginalization." 35 These tensions and legacies are perpetuated by what John Paul Lederach has identified as the "either-or" categories that are often a defining characteristic after conflict: "We are right. They are wrong. We were violated. They are the violators. We are the liberators. They are oppressors. Our intentions are good. Theirs are bad... You are with us or against us." 36 These tensions and legacies continue to feed into the ongoing fermentation of cultural trauma. While individual trauma focuses on the impact on a singular person of an event or series of events, cultural trauma refers to those injurious events that impact entire communities (even as the specific details of experience may vary across individual). Sociologist Jeffrey Alexander writes that "cultural trauma occurs when members of a collectivity feel they have been subjected to a horrendous event that leaves indelible marks upon their group consciousness, marking their memories forever and changing their future identity in

\footnotetext{
34 Waller, Confronting Evil, 169.

35 Ibid.

${ }^{36}$ John Paul Lederach, The Moral Imagination: The Art and Soul of Building Peace (New York: Oxford University Press, 2005), 35.
} 
fundamental and irrevocable ways." 37 Such cultural trauma can pass along unhealed psychological and social wounds that impact the formation of individual and group identities for generations, leaving recovering societies especially vulnerable to future iterations of atrocity. ${ }^{38}$ Without meaningful reparations and rebuilding efforts, these legacies of conflict, grievance, and trauma put a country at risk for future cycles of violence. The impact of the Canadian Indian Residential School System and its corollary cultural trauma provides testament to the importance of this risk category.

For over a hundred years and across multiple generations of families, Canada implemented a residential boarding school system intended to, in the words of Duncan Campbell Scott, the top Indian Agent in Canada when the school system was implemented, "take the Indian out of the child." 39 Started in the 1880s, funded by the Canadian government's Indian Affairs and Northern Development, and run by Christian churches, at least 150,000 indigenous children were forcibly taken from their families and placed into residential religious assimilation schools, where they were forbidden from using their own names, speaking their own languages, wearing their own clothing, or maintaining cultural practices, religions, and relationships. Residential school survivors began implementing legal campaigns to force the government and churches to acknowledge the devastating harm and provide reparations in the 1980s, and the program was finally phased out in the 1990s (the last residential school closed in 1996). 40

When it ended, its devastating toll on Canada's indigenous peoples was almost beyond comprehension. In response to ongoing calls for redress, the federal government finally issued a Statement of Reconciliation that acknowledged the abuse and created the multi-million-dollar Aboriginal Healing Foundation in 1998, and an out-of-court mechanism for determining compensation called the Alternative Dispute Resolution (ADR) process began in 2003. The Indian Residential Schools Settlement Agreement (IRSSA)—notably, it is the largest class action settlement in Canadian history to date-was reached in 2007. It formally recognized the harm done to Indigenous peoples by the residential schools and established a multi-billion-dollar fund to intended help survivors in their recovery. $\$ 60$ million of these funds were set aside for a five-year truth and reconciliation commission intended to provide an opportunity for survivors to give testimony, raise public awareness, and create a "comprehensive historical record" on the residential schools. ${ }^{41}$

When Linda Young, a Plains Cree Indian from Saskatchewan and fourth generation survivor and ward of Saint Anthony's Indian residential school, located in Onion Lake, Saskatchewan, was preparing for her ADR hearing in October 2006, she did not want to forget anything. The process was known to be very difficult and hostile, and she had heard that people were being challenged on everything they said. She decided to type out her testimony and read so she could not be thrown off in the moment. Her testimony was 83 pages long. In it, she described the "sanitizing" process she endured upon arrival. She described her name being discarded and being known only as a number-number 47-for many years. She described how the children were forced into constant prayer and spent so much time on their knees that they

\footnotetext{
37 Jeffrey C. Alexander, "Toward a Theory of Cultural Trauma," in Cultural Trauma and Collective Identity, ed. Jeffrey C. Alexander et al. (Berkeley: University of California Press, 2004), 1.

38 Waller, Confronting Evil, 168.

39 Paul Barnsley, “ADR Process Launched," Windspeaker Publication 21, no. 9 (2003), 11, accessed June 10, 2020, https:// www.ammsa.com/publications/windspeaker/adr-process-launched.

40 The Roman Catholic Church was responsible for 60\% of schools, the Anglican Church for 25\%, and the United and Presbyterian Churches for 15\%. See J. R. Miller, "Residential Schools in Canada," The Canadian Encyclopedia, accessed June 10, 2020, https://www.thecanadianencyclopedia.ca/en/article/residential-schools.

41 Tabitha Marshall, "Indian Residential Schools Settlement Agreement," The Canadian Encyclopedia, accessed June 10, 2020, https://www.thecanadianencyclopedia.ca/en/article/indian-residential-schools-settlement-agreement.
} 
developed thick, white calluses—recognized and referred to as "residential school knees." Her hearing lasted twelve hours. ${ }^{42}$

After the ADR process, Young wanted to place her story in a safe and respectful place. She gathered cloth bags that had been given to her by her mother and bags belonging to her children and cut them into small squares. She printed her ADR testimony on onion skin paper, then tore the pages into strips. Young took the crushed strips of story and, along with one sage leaf each, nestled them into the cut cloth squares to make little bundles, akin to the many tobacco ties she had made over the years. Young made ties until she ran out of story. She used the seams leftover from the cloth bags to tie the bundles, then dipped the ties into wax to seal them and cauterize the emotions within. Young reflected: "Each tie was a small bundle that wrapped painful memories in love, prayer and song." 43 She then took the long string of ties, totaling 250, to form a traditional Cree baby swing, called a wêwêpison. She explained:

Metaphorically speaking, the wêwêpison represents a nurturing environment where culture and language was practiced in the care and raising of a baby-for example, the structure of the swing created a secure and safe environment. The swinging/swaying of the baby swing represents the unborn swinging and swaying in the amniotic fluid (water of life) in the womb. Baby swings were common in First Nations homes; songs / lullabies were sung in our language as we swing the babies to sleep. When we attended the residential schools, we were taken out of the safety of the baby swing, stripped of our culture, our language that guided us and helped us negotiate our nehiyaw environment, our nehiyaw pimatisiwin -our Cree life, and our nehiyaw wiyasiwewina-our Cree laws and teachings. The swing represents giving back the teachings to the little ones who were taken from their mothers, aunties, grandmothers. ${ }^{4}$

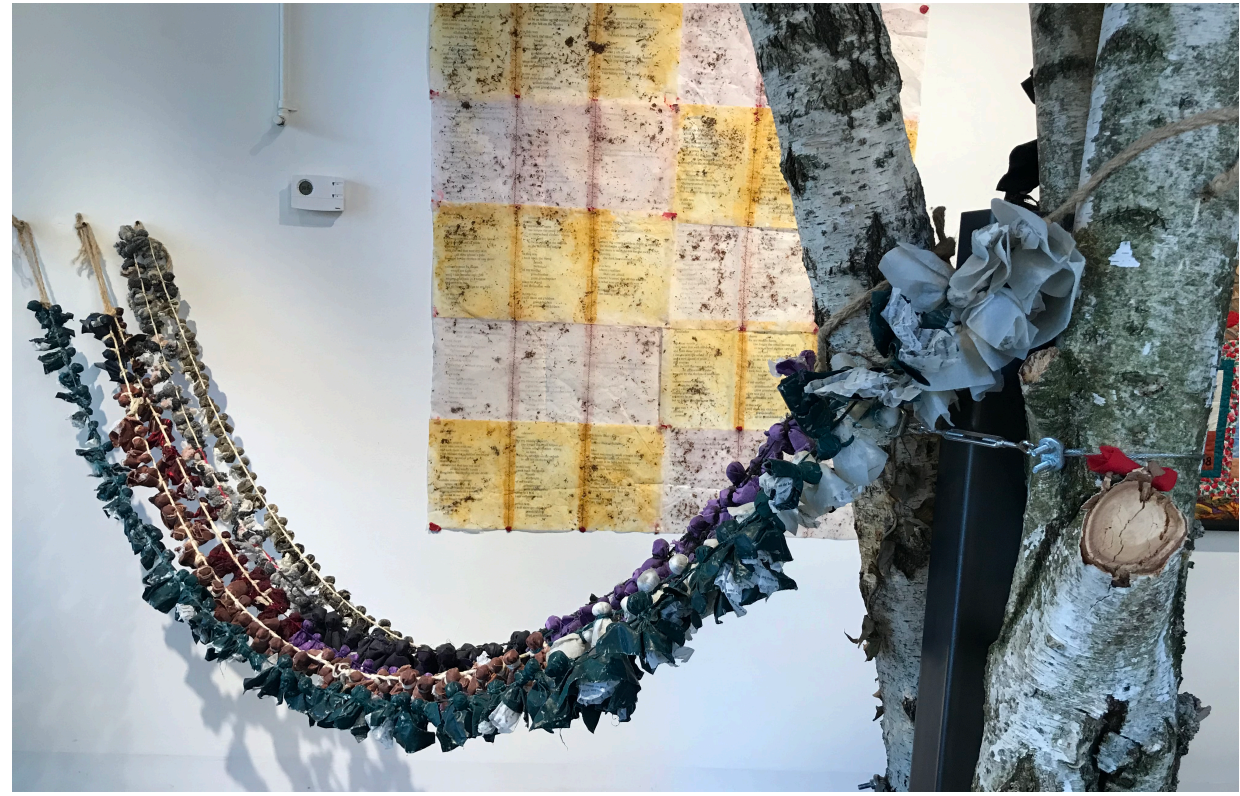

Image 11. Linda Young's wêwêpison and quilt, image courtesy of the author.

\footnotetext{
${ }^{42}$ Linda Young, in conversation with the author, June 2020.

${ }^{43}$ Ibid.

${ }^{44}$ Linda Young, email message to author, June 4, 2020.
} 


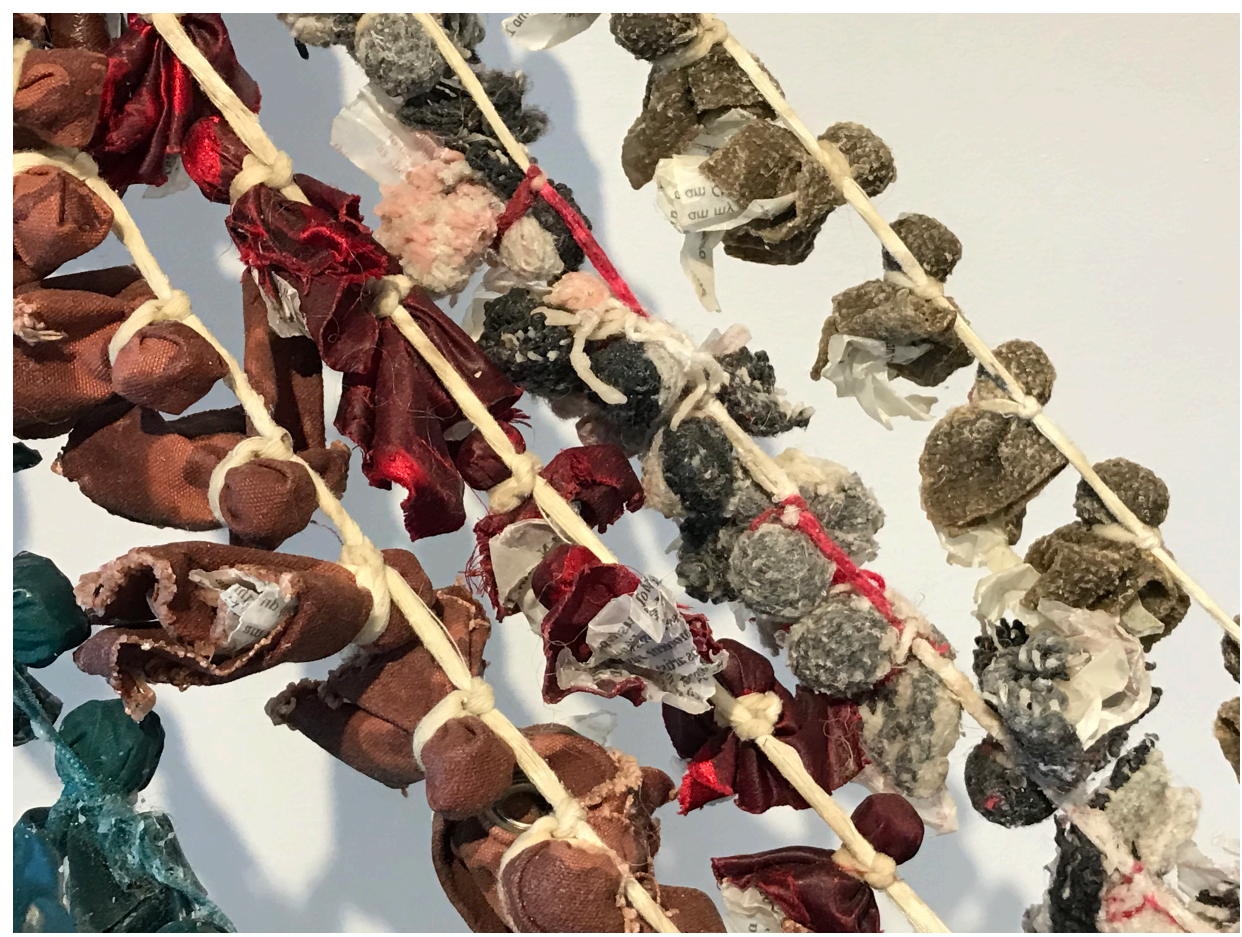

Image 12. The wêwêpison ties, image courtesy of the author.

Young's swing was empty to represent the babies taken from families and placed in the residential schools. Because the wêwêpison also requires a blanket, Young used onion skin paper to make a blanket that hung on the wall behind the swing. The blanket was a patchwork of two poems, one written by Young about her experience being in the residential schools and the other by her daughter Nahanni about being the child of a survivor. This piece-the wêwêpison and blanket-became Young's testimonial submission to the Canadian TRC hearings process. ${ }^{45}$ When Young granted her permission for it to be included in the Artivism Biennale, it was first time the piece had left the National Centre for Truth and Reconciliation archives. 46

In many ways, this piece highlights the complex and multifaceted role art can play in the atrocity prevention process. Meaningful and effective reconciliation necessitates the acknowledgment of injustices and wrongdoings, the addressal of the root causes of the conflict, a recognition of suffering, spaces for healing, and the rewriting of narratives to acknowledge the truths of the past. ${ }^{47}$ In the aftermath of conflict and atrocity, art making can function as a

${ }^{45}$ Young shared the piece in a local group exhibition titled "The Politics of Mother" before submitting it to the TRC.

46 The National Centre for Truth and Reconciliation (NCTR) is the permanent home for all statements, documents, and other materials gathered by Canada's Truth and Reconciliation Commission. Other pieces included Artivism from the Canadian TRC: a vase, a qulliq (soapstone lamp), a recovered brick from a residential school that burned down in 2002, photographs, a collectively-made healing quilt, and a vinyl record and record player.

47 See Cynthia Cohen and Lesley Yalen, "Recasting Reconciliation through Culture and Art: A Virtual Collection: Posting a Theoretical Framework," The International Center for Ethics, Justice, and Public Life at Brandeis University, accessed April 19, 2021, https://www.brandeis.edu/ethics/peacebuildingarts/pdfs/peacebuildingarts/ recasting framewk.pdf; Erin Daly and Jeremy Sarkin-Hughes, Reconciliation in Divided Societies: Finding Common Ground (Philadelphia: University of Pennsylvania Press, 2007); Priscilla B. Hayner, Unspeakable Truths: Confronting State Terror and Atrocities (New York: Routledge, 2002); Ernesto Verdeja, Unchopping a Tree: Reconciliation in the Aftermath of Political Violence (Philadelphia: Temple University Press, 2009). 
powerful practice of healing, reflecting, and cultivating of personal and communal narratives. 48 For Young, the making of the art aided in the healing of her cultural trauma related to decades of devastating, systematic violence inflicted upon her, her family, and her community. She described her art's creation as a reparative act, stating, "I cannot underestimate or forget the deadly impact residential school education has had on my sisters, brothers, aunties, uncles, my mother, my father and step-father, my grandparents and great-grandparents." She continued, "I view my art as medicine. Art helps us heal... I visit a fractured time in history and through art tell a story through the application and handling of the medium. In doing so I am helping heal the generations affected by this incident." 49

The process of sharing art can also be reparative. Waller writes that an important aspect of prevention is for societies to "have in place functioning, open, transparent dispute resolution or transitional justice mechanisms to address legacies of vengeance and grievance" and to encourage remembrance, teaching, and understanding. ${ }^{50}$ The Canadian TRC provided an open forum through which survivors could address grievances and share their testimony, including artistically if so desired, creating a space for art to do what Clara Ramirez-Barat has called the necessary work of "bridging the gap between justice processes and the societies in which they take place." ${ }^{51}$ Such work can assist in the addressal of legacies of violent conflict and encourage collective preventive processes of remembrance and healing. Young's art was a means through which to powerfully and effectively convey the deeply painful loss of family, language, culture, ceremony, and identity and to speak directly to the multigenerational legacy of trauma. The public sharing of art also provided an opportunity to engage in the shared processes of remembrance, learning, and grieving that are so essential to reconciliation and prevention. In our June 2020 conversation, Young described how impressed she was with people's bravery and honesty and how open other survivors were with such painful raw stories and memories. Even though she wanted to leave, she was inspired to honor their honesty and bravery with her own. ${ }^{52}$ Such opportunities to share stories and hear the stories of others can facilitate a collective reflection on the impact of past violence, the breaking down of cultural barriers, and the shared imagining of new futures. Michelle LeBaron writes: "Cultures are like underground rivers that run through our lives and relationships, giving us messages that shape our perceptions, attributions, judgements and ideas of self and other." 53 As such, and as scholars have argued, dialogue is a necessary component of long-term peacebuilding processes because it enables

48 There is an immense wealth of scholarship on diverse intersections of art and trauma, art during and after conflict, art and violence, art and social justice, etcetera. A comprehensive survey is vastly beyond the scope of this article. In addition to scholars cited elsewhere in this article, see, for example: Cynthia E. Cohen et al., eds., Acting Together I: Performance and the Creative Transformation of Conflict: Resistance and Reconciliation in Regions of Violence (New York: New Village Press, 2011); Cynthia E. Cohen et al., eds., Acting Together II: Performance and the Creative Transformation of Conflict: Building Just and Inclusive Communities (New York: New Village Press, 2011); Catherine M. Cole, Performing South Africa's Truth Commission: Stages of Transition (Bloomington: Indiana University Press, 2010); Margarita Saona, Memory Matters in Transitional Peru (Hampshire: Palgrave Macmillan, 2014); Diana Taylor, The Archive and the Repertoire: Performing Cultural Memory in the Americas (Durham: Duke University Press, 2007); Diana Taylor, Theatre of Crisis: Drama and Politics in Latin America (Lexington: University Press of Kentucky, 2014), Diana Taylor, Performance (Durham: Duke University Press, 2016).

49 Linda Young, in conversation with the author, June 2020.

50 Waller, Confronting Evil, 171.

51 Clara Ramírez-Barat, "Introduction: Transitional Justice and the Public Sphere," in Transitional Justice, Culture, and Society: Beyond Outreach, ed. Clara Ramírez-Barat (New York: Social Science Research Council, 2014 ), 29.

52 Linda Young, in conversation with the author, June 2020.

53 Michelle LeBaron, "Culture and Conflict," in Beyond Intractability, eds. Guy Burgess and Heidi Burgess (Conflict Information Consortium, University of Colorado Boulder, July 2003), accessed November 1, 2020, https:// $\underline{\text { www.beyondintractability.org/essay/culture conflict. }}$ 
people to come together to listen to each other and facilitates the shifting of potentially damaging cultural perceptions, judgments, and ideas. ${ }^{54}$

This experience of healing through art making and sharing expanded even further when Young's piece was displayed in the Auschwitz Institute's Artivism Pavilion. Young found the experience extremely powerful, reflecting: "Seeing people be moved by all of the stories of atrocity, it felt very important. That we were working collectively to share a story that is important for the world to hear." 55 She went on to describe a powerful conversation she had at the exhibit's opening. The Ambassador of Canada to Italy came to the event, and when she met Young, she shared that she had not known much about the Indian Residential Schools until she saw Young's work in the exhibit. 56 This point of connection-of learning and listening across difference-is incredibly valuable. As seen here and elsewhere, art making and sharing can function as a reparative form of processing and healing cultural trauma related to institutionalized persecution, repression, oppression, and it is also a mechanism of remembrance and educating about past atrocities that finds purchase on multiple levels: personal, community-based, national, and international. In this capacity, it educates about past atrocities, correcting the public narrative and creating bridges between survivors and the public. As Waller writes: "[C]onflict history in a state or region is a nonmodifiable risk factor for the onset of future genocide-if it happened, it cannot be unhappened. What can be modified, however, are the ways in which that history is remembered, taught, processed, and understood." 57 Violence interrupts the telling of the story and rips apart social fabric. Art can function as thread to begin to stitch it back together.

\section{Social Fragmentation}

The arts can also help mitigate risk factors related to what Waller refers to as social fragmentation, or when societies split into different identity groups that have little or almost no interaction or association with each other. Waller writes: "Where social cohesion can unite a people and strengthen a society, social fragmentation splinters a people, reduces the resiliency of a society, and places it at increased risk for violent or genocidal conflict." ${ }^{58}$ These identitybased social divisions can be especially corrosive, and they are easily susceptible to escalation. Hate speech, for example, can promote the progressive dehumanization of, and then violence toward, another identity group. As Elazar Barkan notes: "[C]onflict between groups is often transgenerational, and the historical animosity remains if it is not addressed. Fear and desire for revenge often linger and inform the policies of the groups involved and are prone to be awakened by nationalists and fundamentalists as carriers of xenophobia." 59 Political instability, demographic pressures and unequal access to basic goods and services between identity groups (even just the perception of differing treatment and access) can all be strong drivers of conflict related to social fragmentation. In order to effectively mitigate risk factors associated with social fragmentation, Waller argues that states have a responsibility to constructively acknowledge and meaningfully accept and support diverse social identities in such a manner that also cultivates a more inclusive superordinate social identification as an "us" rather than many small separate "thems" that mistrust and compete with each other. ${ }^{60}$

\footnotetext{
54 See also David Bohm, On Dialogue (London: Routledge, 2014); Johan Galtung et al., Searching for Peace: The Road to Transcend (London: Pluto Press, 2000); Ereshnee Naidu-Silverman, The Contribution of Art and Culture in Peace and Reconciliation Processes in Asia: A Literature Review and Case Studies from Pakistan, Nepal, Myanmar, Indonesia, Afghanistan, Sri Lanka, and Bangladesh (Copenhagen: Danish Centre for Culture and Development, 2015).

${ }^{55}$ Linda Young, in conversation with the author, June 2020.

56 Ibid.

57 Waller, Confronting Evil, 162.

58 Ibid., 181.

59 Elazar Barkan, "Historical Dialogue and the Prevention of Atrocity Crimes," in Reconstructing Atrocity Prevention, ed. Sheri P. Rosenberg et al. (New York: Cambridge University Press, 2015), 182. ${ }^{60}$ Ibid.
} 
The arts have a critical role in this process. In the most extensive and comprehensive research to date into the impact of the arts, Americans for the Arts (AFTA) found that, across a wide range of arts projects and programs, participation helped reduce isolation, encourage cooperation, and build community networks. Nine out of ten participants said the arts had increased their sense of connection to community; nine out of ten arts participants also described meeting new people and making new friends through their arts experiences. Finally, the AFTA research data also showed that arts participation helped to resolve conflicts and increase tolerance and cross-cultural understanding. ${ }^{61}$ AFTA's research is focused on the arts in the United States, but its breadth and depth makes it an invaluable resource, all the more so because similar research on a broad international or transnational scale does not yet exist.62 Furthermore, it is important to note that AFTA's research results, which highlight the positive effect of arts participation on social cohesion, increased partnerships and intercultural understanding, and reduced fear, are corroborated across numerous, albeit more localized international projects. ${ }^{63}$ Taken as a whole, these studies and projects emphasize the essential role of the arts in encouraging social cohesion and positive intercultural community dialogue, which are essential to atrocity prevention.

In the Artivism exhibit, this was powerfully exemplified by Bosnian artist Aida Šehović's nomadic memorial, ŠTO TE NEMA, which directly engages with the ongoing legacies of conflict history and social fragmentation in Bosnia and Herzegovina and highlights the ability of the arts to address risk factors associated with atrocity and social fragmentation. After Bosnia and Herzegovina declared independence from Yugoslavia in 1992,64 increasing ethno-

61 "Social Impact of the Arts," Americans for the Arts, accessed May 5, 2021, https://www.americansforthearts.org/ socialimpact. For a more comprehensive review of their entire data set as well as the downloadable fact sheets, simply click on "Art" and "Civic Dialogue" on the virtual wheel respectively.

62 This is not to say that there are not larger scale projects happening, but rather that the goal of these projects has not been to produce data similar to AFTA's on an international or transnational scale. For example, I came across a fairly recent project titled the Art of Peace, led by a research team at the University of Manchester, that seeks to investigate the role of grassroots arts in different types and stages of war in Bosnia-Herzegovina, Colombia, Lebanon, and the Democratic Republic of Congo; but at the time of writing, I was unable to find any research or data related to the project. See "The Art of Peace," University of Manchester, accessed November 9, 2020, https:// sites.manchester.ac.uk/the-art-of-peace/home/about/research/. Another project, Art and Reconciliation: Conflict, Culture and Community, was a collaboration between scholars at the King's College London, the London School of Economics, and the University of the Arts in London to investigate post-conflict reconciliation by combining history, political science, art and creative practice. See "Art and Reconciliation: Conflict, Culture and Community," London School of Economics (LSE), November 30, 2016, accessed November 9, 2020, https://blogs.lse.ac.uk/ government/2016/11/30/art-and-reconciliation-looking-at-post-conflict-reconstruction-in-a-different-light/. The project has produced a useful website with project profiles and lists of research publications, but these do not contain like data outputs. See Art \& Reconciliation: Conflict, Culture, and Community (website), accessed April 19, 2021, https: / / artreconciliation.org/.

${ }^{63}$ Brazilian dramaturg and political activist Augusto Boal developed Forum Theatre and Invisible theatre to facilitate dialogue between participants and encourage the breaking down of prejudice and animosity; such theatre-based reconciliation strategies have since gone on to be utilized around the world. See Augusto Boal, Theatre of the Oppressed (New York: Theatre Communications Group, 1985). Such initiatives include Combatants for Peace, a non-profit organization comprised of ex-combatant Israelis and Palestinians working toward peaceful resolution of the occupation and the conflict, and Ajoka Theatre, which strives for a more peaceful, democratic, and just Pakistan. See Combatants for Peace (website), accessed November 9, 2020, https://cfpeace.org/; Ajoka Theatre (website), accessed November 9, 2020, https://ajoka.org.pk/. There are also a number of prominent organizations that do fairly large-scale transnational arts-based prevention work. For example, the Search for Common Ground, one of the largest dedicated peacebuilding organizations, and with a presence in 31 countries across Africa, Asia, Europe, the Middle East, and North America, uses participatory theatre and other creative approaches in their work to transform conflict and violence and promote dialogue and collaboration. See Search for Common Ground (website), accessed November 9, 2020, https://www.sfcg.org/. In Place of War, a global nonprofit that advocates for the use of creativity as a tool for positive change in places of conflict, also seeks to enable grassroots changes through music, theater, and other artforms across twenty-four different sites of conflict, almost all of which are in the global south. See In Place of War (website), accessed November 9, 2020, https:/ / www.inplaceofwar.net/.

${ }^{64}$ For more on the fall of Yugoslavia, see Laura Silber and Allen Little, Yugoslavia: Death of a Nation (New York: Penguin Books, 1997). 
national divisions soon led the new country into war, with violence predominantly occurring between the three principal identity groups of Bosnia and Herzegovina: Bosnian Muslims (Bosniaks), Bosnian Serbs, and Croats. In July 1995, escalating violence and unrest forced thousands of Bosniaks to flee to the United Nations Safe Area for protection. Bosnian Serbs then attacked the Safe Area, and, after relocating most women and girls away from the Safe Area, proceeded to murder the remaining 8,373 men and boys there seeking refuge. 65 This massacre was officially ruled genocide by the International Court of Justice in 2006, but the Bosnia and Herzegovina of today remains deeply segregated, with Bosnian Muslims, Bosnian Serbs, and Croats tending to live, work, and learn only with those from within their own ethnic group. ${ }^{66}$ Each group has their own education system, and while they have similar math and science curricula, they learn different versions of history, each positioning itself as the victim of the other groups. Because there is no consensus among the major ethnic groups about the violence of the 1990s, and Bosnian Serb leaders continue to deny the genocide, these ethnic divisions and tensions continue to be reinforced today. ${ }^{67}$

Seen in Artivism in a dormant state, ŠTO TE NEMA is a nomadic memorial that honors the memory of the 8,372 Bosnian Muslims murdered in the Srebrenica genocide. In the exhibit, visitors encountered large metal shelves stacked with thousands of the small porcelain cups traditionally used for coffee service, an important cultural ritual in Bosnia and Herzegovinabut one day each year, ŠTO TE NEMA is brought to life in the public square of a new city around the world. Every July 11, the anniversary of the genocide, Šehović invites passersby in the square to fill the cups with coffee and place them with the other accumulating cups, collectively contributing to the building of the memorial. ${ }^{68}$ As they pour, volunteers educate participants about the genocide, raising awareness and expanding communities of knowledge. The coffee remains undrunk, in memory of the victims.

When Šehović lays the empty cups down in an urban square and invites others to fill them, she invites them to participate in a shared process of learning, remembering, mourning, and healing. As survivors gift cups to her memorial, it expands to include the voices and memories of thousands. When Šehović first did the performance in 2006, she had 932 cups, given to her by the members of the Women of Srebrenica Association from local families in the region. Today, almost 15 years later, she has 7,714 cups, with the eventual goal of collecting 8,373 cups, one for each victim. Šehović explained the importance of the cups in a June 2020 interview, stating:

I wanted you to feel overwhelmed and to somehow bring the idea of a number closer to you, because we talk about these numbers, and it's like we forget we're talking about human lives. We say 127 or 3,056-but we are talking about human lives. And it drives me crazy when people say 'over 8,000 people'... I know why they say that-because we don't know the precise numbers. We think it's 8,273 , but we're not positive. But it can't be 'over 8,000'-it's not apples. It's humans. So, let's use the numbers. ${ }^{69}$

\footnotetext{
65 Samantha Power, "Bosnia: No More Witnesses at a Funeral," in A Problem from Hell: America and the Age of Genocide (New York: Harper Perennial, 2002), 247-328.

${ }^{66}$ For more on the Bosnian war and genocide, see Rabia Ali and Lawrence Lifschultz, eds., Why Bosnia?: Writings on the Balkan War (Stony Creek: Pamphleteer's Press, 1993).

${ }^{67}$ Auschwitz Institute for Peace and Reconciliation, Artivism: The Atrocity Prevention Pavilion, 2019 (pamphlet).

${ }_{68}$ On July 11, 2019, the cups were removed from the exhibition space so that the monument could be created once more, this time in Venice's Giardini.

${ }^{69}$ Aida Šehović, in conversation with the author, June 2020. Citation first appeared in footnote 1.
} 
Stacked as they were in Artivism exhibit, on metal shelves reminiscent of those used to hold bones and other objects awaiting forensic analysis, the cups really did seem to represent the dead. Non-distinct from a distance, when viewers stepped closer the cups were recognizably individual, possessed of their own unique characteristics: a splash of delicate blush-colored flowers, fine vertical lines, trimmed in gold, polka dots, vibrant blue with an etched white design. Each one of these cups represents an individual person, a person who could have been sharing coffee with family and friends but was instead killed. With the cups serving as reminders of individual lives lost in Herzegovina and the poured-but not drunkcoffee of the ongoing felt presence of their absence, ŠTO TE NEMA is a powerful reminder that such genocidal loss is comprised of many individual stories and lost loved ones whose memory must continue to be recognized and honored.

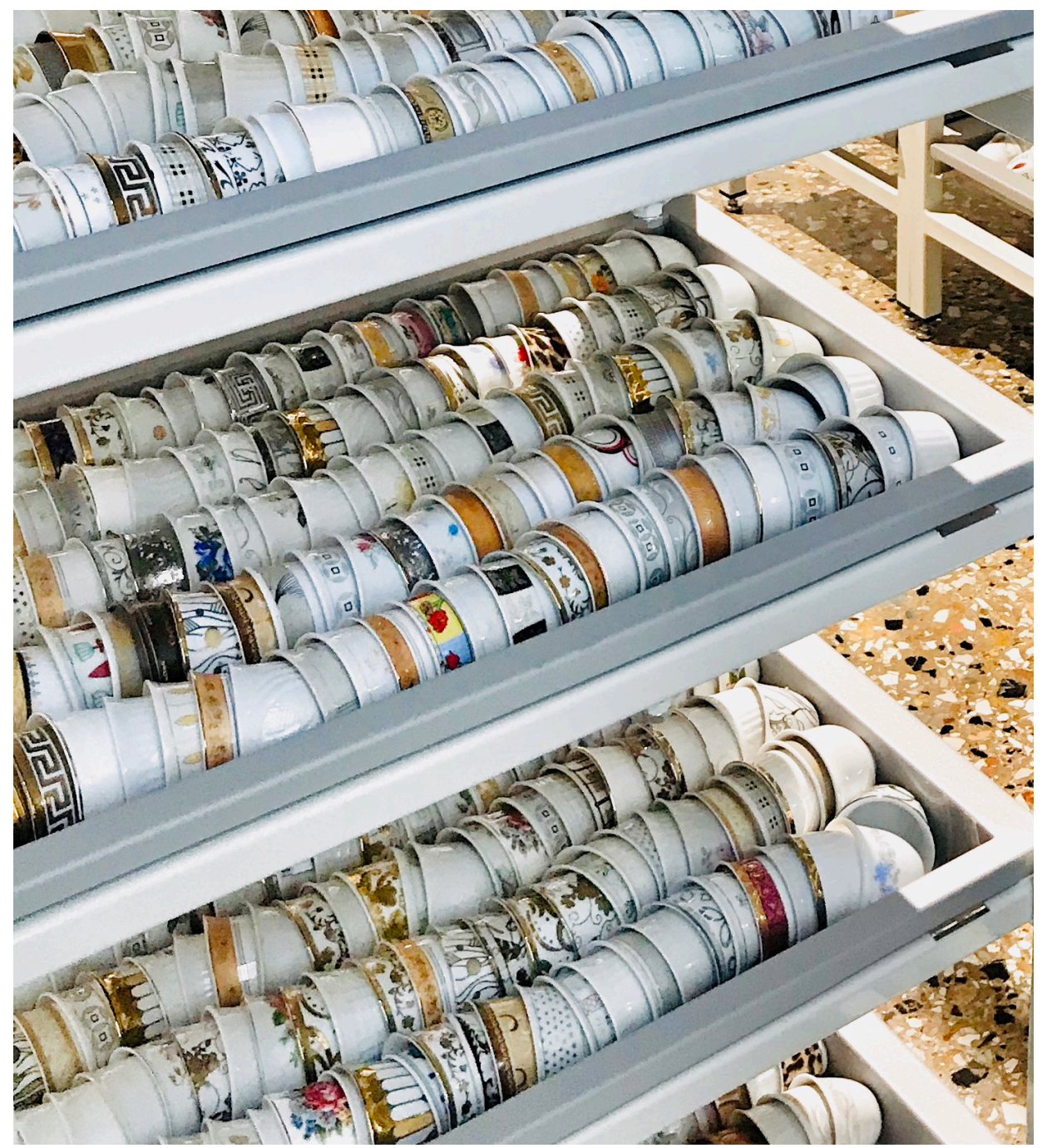

Image 13. STO TE NEMA, image courtesy of the author

The telling, listening to, and revising of stories is essential to the restoration of fractured relationships and the development of more peaceful communities. As Cynthia Cohen writes, telling and listening to stories is essential to the peacebuilding process because it is through the sharing of stories that "former enemies come to understand each other's experiences, the meaning each community attaches to historical events, and their moral sensibilities."70 This

70 Cynthia Cohen, “Creative Approaches to Reconciliation," in The Psychology of Resolving Global Conflicts: From War to Peace: Volume 3: Interventions, ed. Mari Fitzduff and Christopher E. Stout (Westport, CT: Greenwood Publishing Group, 2005), 15. 
shared work of telling and listening is "critical to coexistence work because collective narratives are closely linked with social identities. To change identities, we must revise our stories, and revising stories can create social, emotional and intellectual spaces for more nuanced understandings of identity."71 This is further corroborated by another AFTA study that found that participation in arts activities markedly increases tolerance. For example, in a study of US high schoolers, AFTA found that students who participated in the arts were forty percent more likely to have friends from different racial groups and twenty-nine percent less likely to think it was acceptable to make racist remarks. The research also emphasized the crucial role of the arts in bringing together children from immigrant and resident populations and found that arts programming created a common bridge that promoted friendship, empathy and mutual trust.72 Again, while this research was not done through the lens of genocide prevention, these results nonetheless have powerful implications for mitigating risk factors associated with genocide and mass atrocity because they emphasize the power of the arts to encourage people to literally and figuratively come together to listen and be listened to, to engage side by side in shared activities, and to cultivate community, self-reflection, and empathy for others-all of which are necessary to the diminution of social fragmentation and growth of social cohesion. Along similar lines, Rachel Kerr argues that "it is precisely the idea that the engagement is openended, and not predetermined, that is valuable. The arts can accommodate difference, not seek a single didactic "truth."'73 This ability to create a pathway to meaningful dialogue and learning across difference is essential to prevention.

Ending cycles of violence-whether it is recovering from previous conflict or preventing future conflict-necessitates functioning relations grounded in connection and support-both felt and practiced-between those in governance and society and between the identity groups of which society is comprised. ŠTO TE NEMA, exhibited in Artivism in dormant format, is a reminder that reconciliation and prevention are intricately linked, multifaceted processes that rely upon increased and shared understanding, trust, and respect to effectively dismantle entrenched grievances and social fragmentation. As Sarah Madison writes, reconciliation is both process and goal and requires "a change of values, a willingness to venture beyond the promotion of rigid identities that result in war and cultivate a new attitude towards others." This is the basis from which to address the "major material and structural challenges that so often cause post-conflict societies to slide back into war..."74 This is akin to what John Lederach has called the "moral imagination" - the ability to be grounded in the realities of the present while imagining and working toward a different world. ${ }^{75}$ Artistic interventions like ŠTO TE NEMA can play a critical role in this process because they encourage people to stop, listen, learn, and connect. In our conversation, Šehović reflected: "Art can be the way toward preventing violence. For people who feel safe and comfortable, whose life is safe and comfortable, it's really, really hard for them to understand, without disrupting their comfort and safety, to understand, even in a small form, what it means to not be safe, what it means to be hurt."76 However, she believes that artistic interventions like ŠTO TE NEMA have a very unique role in making that violence accessible. Šehović explained:

If you are someone who has never felt unsafe, has never felt that your identity has been threatened, if you hold that cup in your hand, you are connected forever. You can never tell me

\footnotetext{
${ }^{71}$ Ibid.

72 Americans for the Arts, Social Impact of the Arts. Citation first appeared in footnote 59.

${ }^{73}$ Rachel Kerr, "Art, Aesthetics, Justice, and Reconciliation: What Can Art Do?," AJIL Unbound 114 (2020), 127, accessed November 1, 2020, https://doi.org/10.1017/aju.2020.24.

${ }^{74}$ Sarah Maddison, Conflict Transformation and Reconciliation: Multi-Level Challenges in Deeply Divided Societies (London: Routledge, 2016), 46.

${ }^{75}$ Lederach, The Moral Imagination, 3.

76 Aida Šehović, in conversation with the author, June 2020.
} 
you don't know. Your understanding of Srebrenica and hopefully all genocide and atrocities changes, because here you were holding a cup that represents one human who was killed because of who they were. ${ }^{77}$

This intimate connection to the past, this ability to hold it in one's hands and to understand it as an individual life lost, can create shared spaces of remembering and mourning, listening and learning, and envisioning and committing to more peaceful futures. As Rachel Kerr argues, effective reconciliation requires the "ongoing processes of building relationships and mutual respect that are crucial to social repair."78 And while the arts are and should not be considered a replacement for more formal policy-based processes, "the arts can provide a 'creative pathway' to reconciliation, breaking silences, transforming relationships, communicating across cultural divides and providing a means of dealing with trauma and restoring human dignity."79 Effective atrocity prevention requires the meaningful encouragement and development of social cohesion, aided by efforts to imagine and cultivate different sets of relationships and ways of thinking and being in community. This is a goal and process to which arts initiatives can make a profound contribution.

\section{Governance}

The final category of risk factors for violent or genocidal conflict addressed here is that of governance. Waller broadly defines governance as how authority is exercised, inclusive of how governments are selected, monitored, and replaced, their capacity to develop and implement policy, and the degree to which citizens trust and respect the state and its representing institutions. ${ }^{80}$ The five risk factors Waller outlines-regime type, legitimacy deficit, weakness of state structures, identity-based polar factionalism, and systematic acts of discrimination-have far reaching impact. Without strong and functioning structures, states cannot provide basic services and uphold the law. People will not trust the state if it is not seen as functional, legitimate, law-abiding, and impartial. Governmental factionalism and discrimination against identity groups, including through such actions as the removal of civil liberties, arbitrary detention or imprisonment, or unequal access to education is deeply corrosive to efficacy, trust, and public safety.

Obviously, arts initiatives are unlikely to instantly transform a dictatorship into a democracy, but they are remarkably powerful in calling attention to corruption and impunity and influencing public opinion about the state and official processes. ${ }^{81}$ As Whigham writes:

Although it may be true that the most visible and widely discussed aspects of dealing with the past-from truth commissions to criminal prosecution to reparations to institutional reform-require the participation of governmental actors, the fact remains that most of these processes initiate through a movement from the grassroots that begins long

\footnotetext{
77 Ibid.

78 Rachel Kerr, "The 'Art' of Reconciliation," FICHL Policy Brief Series 78 (2017), 3, accessed November 1, 2020, https:// www.toaep.org/pbs-pdf/78-kerr/. 
before the state opts to assume responsibility for these projects. ${ }^{82}$

Put simply, those who implement oppressive, violent power systems are unlikely to press for their own accountability, just as those who directly benefit from those systems are unlikely to lead the charge for their change. But arts initiatives, especially at the grassroots level, can be an invaluable and powerful means of calling out atrocity and human rights abuses, activating dialogue, educating others, and demanding change. In Canada, Young's artwork conveys the damages done to generations of indigenous communities through systematic stateled discrimination and takes part in a public reckoning and healing process. Meanwhile, GAC, in Argentina, is an excellent example of the role artistic activists can play in repudiating statesupported impunity and demanding change. Their creative efforts, along with that of other activist groups, strengthened Argentina's then-young democracy and helped bring about change in Argentina, which eventually revoked the impunity laws and reopened perpetrator trials. The Trial of the Juntas was the first largescale trial by a democratic government against a former military dictatorial government of the same country in all of Latin America. ${ }^{83}$

Mulyani's artwork addresses the ongoing need for reparations in Indonesia, where the genocide has yet to be formally acknowledged by the Indonesian government, nor have there been formal reparations efforts. Of her two pieces in Artivism, the first, "Oleh-oleh" [Souvenir], is a sculptural and sound installation comprised of a row of thirteen ears displayed on the wall to commemorate thirteen activists who were kidnapped in the 1990s for dissent against the dictatorial regime that began in 1965. ${ }^{84}$ Her second piece, "Supervivere," is a photography series depicting the lives of a number of Indonesian exiles currently living in Belgium, Sweden, and the Netherlands after their citizenship was revoked and they were made stateless by the Indonesian government in 1965. Works such as these call powerful attention to ongoing silences and erasures and point to the pervasive impact still experienced throughout the Indonesian diaspora decades after the genocide.

Art initiatives can also bring attention to ongoing human rights abuses that have been insufficiently addressed by the national and international community. For example, Chalak's face castings address the ongoing ISIS violence against the Yazidi people in Iraq (including forced conversion to Islam or murder, the kidnapping of Yazidi boys to be ISIS fighters, and the kidnapping, rape, and nonconsensual marriage of Yazidi women and girls). Wanting to share the women's stories and raise international awareness and condemnation of this ongoing genocide but worried that identifying the women would put them women at further risk, Chalak began casting masks of their faces as a form of representation without identification. He takes these masks around the world, creating opportunities for people to try on the masks themselves, giving powerful new meaning to the concept of putting yourself in someone else's shoes. Chalak has created 23 masks to date, all of which were displayed in Artivism woven through and beyond a metal cage reminiscent of those in which many Yazidi women have been held. Across these different examples, the artworks exhibited in Artivism highlight arts' role in demanding governmental accountability and an end to corruption, contributing to helping rebuild society's trust, and strengthening transition, justice, and prevention processes.

\section{Conclusion}

Art is not a panacea for violent conflict, and atrocity prevention is complex, ongoing work. Indeed, and as scholars have noted, there is no guarantee that art will necessarily lead to

\footnotetext{
82 Kerry E. Whigham, "Remembering to Prevent: The Preventive Capacity of Public Memory," Genocide Studies and Prevention: An International Journal 11, no. 2 (2017), 58, accessed August 1, 2019, http://doi.org/ $\underline{10.5038 / 1911-9933.11 .2 .1447 .}$

83 “Juicio a la Juntas Militares," International Crimes Database, accessed April 23, 2021, http:/ / www.internationalcrimesdatabase.org/ Case $/ 1118$.

${ }^{84}$ Although only 13 ears were displayed in Artivism, the complete Oleh-oleh [Souvenir] comprises 169 ears arranged on the wall in 13 rows of 13 .
} 
decreased violence and increased cohesion. 85 Art is adiaphorous; it can have positive and negative effects (there are examples throughout history of when the arts have been used in service of the perpetuation of violence and not its cessation); it can also have no effect. ${ }^{86}$ As Cohen writes: "Whether intentionally or not, creative initiatives can... reinforce power inequities, retraumatize communities, perpetuate harmful stereotypes, trivialize suffering, reactivate hostilities and demean sacred cultural forms." 87 But, she continues, "when care is taken to minimize risks of harm.... artistic and cultural processes can be crafted to engage individuals and communities in transforming consciousness, building relationships and reimagining the future." 88 The Artivism exhibit, in its collection and range, provides a canvasing of multiple and directed creative interventions that allow for a kind of understanding of atrocity as a global problem. It isn't limited to region, issue, language, or religion; conflict impacts across multiple generations; and without meaningful prevention efforts, genocide and atrocity will continue to remain a very real risk. However, Artivism effectively created a space for audiences to bear witness ${ }^{89}$ to survival and engage in what has in scholarship at times been called "ethical spectatorship,"90 "seeing for,"91 "empathic vision,"92 "ethical imagination,"93 and "ethical vision," 94 and then consider their own role in prevention. As noted earlier, the importance of this should not be underestimated: increased public awareness leads to increased support and calls for change, followed by action and actual change. Furthermore, it modeled for governments how they might learn from, engage with, and support different arts-based prevention efforts in their own countries. It also highlighted our collective responsibility to actively participate in prevention efforts. This lesson seemed especially powerful in the context of the Venice Biennale networks of power and prestige, and it brought to mind what Michael Rothberg has called the implicated subject. Rothberg writes:

\footnotetext{
85 See, for example, the films used for Nazi propaganda, or Hitler's intricately choreographed marches.

${ }^{86}$ Cynthia Cohen, "Reimagining Transitional Justice," International Journal of Transitional Justice 14, no. 1, (2020), 2; Kerr, The 'Art' of Reconciliation, 3.

87 Cohen, Reimagining Transitional Justice, 2.

88 Ibid.

89 The phrase "to bear witness" is widely used across disciplines, although it perhaps appears most prevalently in scholarship on memory and trauma. On one level, "to witness" is relatively straightforward: it is literally to see, to attest to fact or event. This is the level of witnessing at which the live, or eye, witness operates. The concept of witnessing also expands beyond the level of the live witness to incorporate a sense of shared responsibility on the part of the viewer. Writing about the Eichmann Trial, Annette Wieviorka asserts that the witness is the "bearer of history," and an "embodiment of memory, attesting to the past and to the continuing presence of the past." See Annette Wieviorka, The Era of the Witness, trans. Jared Stark (Ithaca: Cornell University Press, 2006), 88. In Seeing Things, John Ellis describes witnessing as a distinct mode of perception, wherein we can no longer say we do not know. See John Ellis, Seeing Things: Television in the Age of Uncertainty (London: I.B. Tauris, 2000). Similarly, John Peters writes: "To witness an event is to be responsible in some way to it." In other words, to bear witness is not "just" to see or verify, but to intellectually and affectively acknowledge the magnitude of an event, and feel its weight. To bear witness, either directly or indirectly, is to share in the responsibility for what has occurred and is yet to come. See John Durham Peters, "Witnessing," Media, Culture, and Society 23, no. 6 (2016), 708, accessed August 1, 2020, https:/ / doi.org/10.1177/016344301023006002.
}

90 Wendy Kozol, Distant Wars Visible: The Ambivalence of Witnessing (Minneapolis: University of Minnesota Press, 2014), 16

91 Mieke Bal, "The Pain of Images," in Beautiful Suffering: Photography and the Traffic in Pain, ed. Mark Reinhardt et al. (Chicago: University of Chicago Press, 2007), 93-115.

92 Jill Bennett, Empathic Vision: Affect, Trauma, and Contemporary Art (Palo Alto: Stanford University Press, 2005).

93 Elizabeth Swanson Goldberg, "Who Was Afraid of Patrice Lumumba? Terror and the Ethical Imagination in Lumumba: La Mort du Prophet," in Terrorism, Media, Liberation, ed. J. David Slocum (New Brunswick: Rutgers University Press), 248-266.

${ }^{94}$ Kyo Maclear, "The Limits of Vision: Hiroshima Mon Amour and the Subversion of Representation," in Witness and Memory: The Discourse of Trauma, eds. Ana Douglass and Thomas A. Vogler (New York: Routledge), 233-248. 
Implicated subjects occupy positions aligned with power and privilege without being themselves direct agents of harm; they contribute to, inhabit, inherit, or benefit from regimes of domination but do not originate or control such regimes. An implicated subject is neither a victim nor a perpetrator, but rather a participant in histories and social formations that generate the positions of victim and perpetrator, and yet in which most people do not occupy such clear-cut roles. ${ }^{95}$

Implicated subjects are not perpetrators, but they benefit from and participate in structures of inequality. By not just asking audiences to take seriously the question of how they might actively contribute to prevention efforts, but also giving them concrete examples of how they could contribute from and within their own communities in just sixty seconds, sixty minutes, or sixty days, the Artivism exhibit underscored that, just as we are all participants in intersecting and overlocking histories and social formations, we all have a shared responsibility to actively participate in the prevention of genocide and mass atrocity.

Given the sheer numbers of international visitors to the Biennale, this message was especially important. The exhibit asks visitors to not look away-from the art and the specific conflict contexts from which each piece originated, but most importantly from the urgency of the call for a shared commitment in prevention. Artivism brings prevention work to audiences who may have had very little prior contact with the field and asks visitors to take the work home with them. It extends the reach of the artworks displayed therein, finding for them new audiences and broader cross-cultural awareness. But Artivism does not just display powerful examples of atrocity prevention, the exhibit also actively contributes to prevention by arguing that meaningful genocide and atrocity prevention will take each and every one of us and asking for a commitment to supporting and cultivating prevention efforts all across the globe. The power and reach of this ask are profound.

Across this study, there are a number of important takeaways. First, the arts have a critical role to play in mitigating risk factors associated with genocide and mass atrocities. This includes through healing to break cycles of violence and trauma, educating to promote a collective story and cultivate moral imagination, sharing to generate bridges between estranged groups and identities, and awareness-raising to address governmental weakness and inaction. Second, this has important ramifications for future prevention efforts because it highlights the importance of meaningful integration and support for the arts as prevention. This includes, but is not limited to the following: The arts should be incorporated into reconciliation and community building and strengthening projects that engage all different aspects of a community. Collaborations between artists, state actors, and civil society should be encouraged and supported. Programs and spaces should be created to enable artists as well as their state and community collaborators to exchange ideas and best practices and build relationships and networks of accountability and support. Funding and grants programs to support artistic residencies, collaborations, and the creation of new works should be prioritized, as well as increased investment in infrastructure for the arts, such as community centers, theaters, galleries, and other public spaces. Finally, further study is required. Advancing the impact of the arts in atrocity prevention requires more targeted arts programming, closely documented case studies, appropriate models of evaluation and assessment, and scholarly attention. I have sketched out a framework for arts-based prevention analysis and employed it in analysis of a series of arts initiatives from differing regional and conflict contexts. Deeper exploration into different art forms and projects or conflicts and their corollary preventive efforts is beyond the scope of this essay. My hope is that this will serve as an intervention into an ongoing scholarly conversation and, as called for by Šehović in the opening epigraph, animate powerful new possibilities for the study and practice of arts-based genocide and atrocity prevention.

${ }_{95}$ Michael Rothberg, The Implicated Subject: Beyond Victims and Perpetrators (Stanford: Stanford University Press, 2019$), 1$. 


\section{Bibliography}

Alexander, Jeffrey C. "Toward a Theory of Cultural Trauma." In Cultural Trauma and Collective Identity, edited by Jeffrey C. Alexander, Ron Eyerman, Bernard Giesen, Neil J. Smelser, and Piotr Sztompka, 1-30. Berkeley: University of California Press, 2004.

Ali, Rabia and Lawrence Lifschultz, eds. Why Bosnia?: Writings on the Balkan War. Stony Creek: Pamphleteer's Press, 1993.

Americans for the Arts. "Social Impact of the Arts." Accessed May 5, 2021. https:// www.americansforthearts.org/socialimpact.

Asante Jr., M. K. It's Bigger Than Hip Hop. London: St. Martin's Press, 2009.

Auschwitz Institute for Peace and Reconciliation. Artivism: The Atrocity Prevention Pavilion. 2019. Pamphlet.

Auschwitz Institute for the Prevention of Genocide and Mass Atrocities. "Lemkin Seminar, Global Edition." Accessed April 23, 2021. https://www.auschwitzinstitute.org/whatwe-do/global-programs/.

Australian National University. "Atrocity Forecasting Project." Accessed July 10, 2020. https:// politicsir.cass.anu.edu.au/research/projects/atrocity-forecasting.

Bal, Mieke. "The Pain of Images." In Beautiful Suffering: Photography and the Traffic in Pain, edited by Mark Reinhardt, Holly Edwards, and Erina Duganne, 93-115. Chicago: University of Chicago Press, 2007.

Barkan, Elazar. "Historical Dialogue and the Prevention of Atrocity Crimes." In Reconstructing Atrocity Prevention, edited by Sheri P. Rosenberg, Tibi Galis, and Alex Zucker, 175-195. New York: Cambridge University Press, 2015.

Barnsley, Paul. "ADR Process Launched." Windspeaker Publication 21, no. 9 (2003), 11. Accessed June 10, 2020. https://www.ammsa.com/publications/windspeaker/adr-processlaunched.

Bennett, Jill. Empathic Vision: Affect, Trauma, and Contemporary Art. Palo Alto: Stanford University Press, 2005.

Boal, Augusto. Theatre of the Oppressed. New York: Theatre Communications Group, 1985.

Bohm, David. On Dialogue. London: Routledge, 2014.

Boyson, Oscar, dir. "Behind the Biennale: A Short History of the World's Most Important Art Exhibition." Uploaded May 3, 2015, Artsy. Accessed June 20, 2020. https:// www.artsy.net/article/artsy-editorial-behind-the-venice-biennale-2015-a-short-historyof-the-world-s-most-important-art-exhibition.

Cohen, Cynthia. "Creative Approaches to Reconciliation." In The Psychology of Resolving Global Conflicts: From War to Peace: Volume 3: Interventions, edited by Mari Fitzduff and Christopher E. Stout, 69-102. Westport, CT: Greenwood Publishing Group, 2005.

"Reimagining Transitional Justice." International Journal of Transitional Justice 14, no. 1, (2020), 1-13.

Cohen, Cynthia and Lesley Yalen. "Recasting Reconciliation through Culture and Art: A Virtual Collection: Posting a Theoretical Framework." The International Center for Ethics, Justice, and Public Life at Brandeis University. Accessed April 19, 2021. https:// www.brandeis.edu/ethics/peacebuildingarts/pdfs/peacebuildingarts/ recasting framewk.pdf.

Cohen, Cynthia E., Roberto Gutiérrez Varea, and Polly O. Walker, eds. Acting Together I: Performance and the Creative Transformation of Conflict: Resistance and Reconciliation in Regions of Violence. New York: New Village Press, 2011.

-------. Acting Together II: Performance and the Creative Transformation of Conflict: Building Just and Inclusive Communities. New York: New Village Press, 2011.

Cole, Catherine M. Performing South Africa's Truth Commission: Stages of Transition. Bloomington: Indiana University Press, 2010.

Daly, Erin and Jeremy Sarkin-Hughes. Reconciliation in Divided Societies: Finding Common Ground. Philadelphia: University of Pennsylvania Press, 2007. 
Ebrahim, Alnoor, and V. Kasturi Rangan. "The Limits of Nonprofit Impact: A Contingency Framework for Measuring Social Performance." Working Paper 10-099, Harvard Business School, Cambridge, MA, 2010.

Ellis, John. Seeing Things: Television in the Age of Uncertainty. London: I.B. Tauris, 2000.

Galtung, Johan, Carl G. Jacobsen, and Kai Frithjof Brand-Jacobsen. Searching for Peace: The Road to Transcend. London: Pluto Press, 2000.

Harff, Barbara. "Assessing Risk of Genocide and Politicide." In Peace and Conflict: A Global Survey of Armed Conflicts, Self-Determination Movements, and Democracy, edited by Monty G. Marshall and Ted Robert Gurr, 57-61. College Park: University of Maryland Press, 2005.

Hayner, Priscilla B. Unspeakable Truths: Confronting State Terror and Atrocities. New York: Routledge, 2002.

International Crimes Database. "Juicio a la Juntas Militares." Accessed April 23, 2021. http:// www.internationalcrimesdatabase.org/Case/1118.

Kerr, Rachel. "Art, Aesthetics, Justice, and Reconciliation: What Can Art Do?." AJIL Unbound 114 (2020), 123-127. Accessed November 1, 2020. https:// doi.org/10.1017/aju.2020.24.

------. "The 'Art' of Reconciliation." FICHL Policy Brief Series 78 (2017). Accessed November 1, 2020. https: / / www.toaep.org/pbs-pdf/78-kerr/.

Kozol, Wendy. Distant Wars Visible: The Ambivalence of Witnessing. Minneapolis: University of Minnesota Press, 2014.

LeBaron, Michelle. "Culture and Conflict." Beyond Intractability, edited by Guy Burgess and Heidi Burgess. Conflict Information Consortium, University of Colorado Boulder, July 2003. Accessed November 1, 2020. https://www.beyondintractability.org/essay/ culture conflict.

Lederach, John Paul. The Moral Imagination: The Art and Soul of Building Peace. New York: Oxford University Press, 2005.

London School of Economics (LSE). "Art and Reconciliation: Conflict, Culture and Community." November 30, 2016. Accessed November 9, 2020. https://blogs.lse.ac.uk/ government / 2016/11/30/art-and-reconciliation-looking-at-post-conflictreconstruction-in-a-different-light/.

Maclear, Kyo. "The Limits of Vision: Hiroshima Mon Amour and the Subversion of Representation." In Witness and Memory: The Discourse of Trauma, edited by Ana Douglass and Thomas A. Vogler, 233-248. New York: Routledge, 2003.

Maddison, Sarah. Conflict Transformation and Reconciliation: Multi-Level Challenges in Deeply Divided Societies. London: Routledge, 2016.

Marshall, Tabitha. "Indian Residential Schools Settlement Agreement." The Canadian Encyclopedia. Accessed June 10, 2020. https://www.thecanadianencyclopedia.ca/en/ article/indian-residential-schools-settlement-agreement.

McLagan, Meg. "Imagining Impact: Documentary Film and the Production of Political Effects." In Sensible Politics: The Visual Culture of Nongovernmental Activism, edited by Meg McLagan and Yates McKee, 305-319. New York: Zone Books, 2012.

Miller, J. R. "Residential Schools in Canada." The Canadian Encyclopedia. Accessed June 10, 2020. https://www.thecanadianencyclopedia.ca/en/article/residential-schools.

Naidu-Silverman, Ereshnee. "The Contribution of Art and Culture in Peace and Reconciliation Processes in Asia: A Literature Review and Case Studies from Pakistan, Nepal, Myanmar, Indonesia, Afghanistan, Sri Lanka, and Bangladesh." Copenhagen: Danish Centre for Culture and Development, 2015.

National Endowment for the Arts. "Arts Data Profile Series." Accessed April 24, 2021. https:// www.arts.gov/impact/research/arts-data-profile-series.

Peters, John Durham. "Witnessing." Media, Culture, and Society 23, no. 6 (2016), 707-723. Accessed August 1, 2020. https:// doi.org/10.1177/016344301023006002.

Power, Samantha. "Bosnia: No More Witnesses at a Funeral." In A Problem from Hell: America and the Age of Genocide, 247-328. New York: Harper Perennial, 2002. 
Ramírez-Barat, Clara. "Introduction: Transitional Justice and the Public Sphere." In Transitional Justice, Culture, and Society: Beyond Outreach, edited by Clara Ramírez-Barat, 26-45. New York: Social Science Research Council, 2014.

Rothberg, Michael. The Implicated Subject: Beyond Victims and Perpetrators. Stanford: Stanford University Press, 2019.

Rugoff, Ralph. "Introduction by Ralph Rugoff: Curator of the 58th International Art Exhibition." La Biennale di Venezia. Accessed May 1, 2019. https://www.laBiennale.org/en/art/ 2019/ introduction-ralph-rugoff.

Sandoval, Chela and Guisela Latorre. "Chicana/o Artivism: Judy Baca's Digital Work with Youth of Color." In Learning Race and Ethnicity, edited by Anna Everett, 81-108. Boston: MIT Press, 2007.

Saona, Margarita. Memory Matters in Transitional Peru. Hampshire: Palgrave Macmillan, 2014.

Silber, Laura and Allen Little. Yugoslavia: Death of a Nation. New York: Penguin Books, 1997.

Swanson Goldberg, Elizabeth. "Who Was Afraid of Patrice Lumumba? Terror and the Ethical Imagination in Lumumba: La Mort du Prophet." In Terrorism, Media, Liberation, edited by J. David Slocum, 248-266. New Brunswick: Rutgers University Press, 2005.

Taylor, Diana. Performance. Durham: Duke University Press, 2016.

------. The Archive and the Repertoire: Performing Cultural Memory in the Americas. Durham: Duke University Press, 2003.

-------. Theatre of Crisis: Drama and Politics in Latin America. Lexington: University Press of Kentucky, 2014.

United Nations. Framework of Analysis for Atrocity Crimes: A Tool for Prevention. UN Office on Genocide Prevention and the Responsibility to Protect, 2014.

United States Holocaust Memorial Museum and Dartmouth College. "Early Warning Project." Accessed June 1, 2020. https:/ / earlywarningproject.ushmm.org/.

University of Manchester. "The Art of Peace." Accessed November 9, 2020. https:// sites.manchester.ac.uk/the-art-of-peace/home/about/research/.

University of Maryland. "The Minorities at Risk (MAR) Project." Accessed June 30, 2020. http://www.mar.umd.edu/.

Verdeja, Ernesto. Unchopping a Tree: Reconciliation in the Aftermath of Political Violence. Philadelphia: Temple University Press, 2009.

Waller, James. Confronting Evil: Engaging Our Responsibility to Prevent Genocide. New York: Oxford University Press, 2016.

Whigham, Kerry E. "Remembering to Prevent: The Preventive Capacity of Public Memory." Genocide Studies and Prevention: An International Journal 11, no. 2 (2017), 53-71. Accessed August 1, 2019. http:/ / doi.org/10.5038/1911-9933.11.2.1447.

Wieviorka, Annette. The Era of the Witness. Translated by Jared Stark. Ithaca: Cornell University Press, 2006. 